\title{
Geochemical Characterization of Vertisols Developed on Granites from Kaele, North-Cameroon: Implications for REE Exploration
}

\author{
Elisabeth Yaboki ${ }^{1}$, Jean Pierre Temga ${ }^{2 *}$, Elisé Sababa ${ }^{2}$, Simon Djakba Basga ${ }^{3}$ and Jean Pierre Nguetnkam $^{1}$ \\ ${ }^{1}$ Department of Earth Sciences, University of Ngaoundéré, P.O. Box, 454 Ngaoundéré, Cameroon
}

${ }^{2}$ Department of Earth Sciences, University of Yaoundé I, P.O. Box, 812 Yaoundé, Cameroon

${ }^{3}$ Institute of Agricultural Research for Development (IRAD), P.O. Box 415 Garoua, Cameroon

*Corresponding author: Jean Pierre Temga, Department of Earth Sciences, University of Yaoundé I, P.O. Box, 812 Yaoundé, Cameroon.
Received Date: March 24, 2021

Published Date: March 31, 2021

\begin{abstract}
This paper presents the geochemical features of Vertisols developed on granites from Kaele, North Cameroun. The mineralogy of soil samples was determined by X-ray diffraction (XRD). X-ray Fluorescence (XRF) and Inductively Coupled Plasmas-Mass Spectrometry (ICP-MS) have been used to determine major and trace element including rare earth elements compositions of granite and soil samples. Granite samples consist of feldspars (orthoclase, plagioclase), quartz, biotites and opaque minerals. They have peraluminous composition and of S-type granite. They also have high contents in $\mathrm{Ba}, \mathrm{Cr}, \mathrm{Sr}, \mathrm{Zr}$ and low $\mathrm{REE}$ contents with variable Eu anomaly values. The mineralogical and geochemical features of Vertisols corroborate with the parent rock nature and the intensity of weathering process. The Fe-oxide precipitation, the presence of kaolinite and calcareous nodules are responsible for significant contents in $\mathrm{Fe} 2 \mathrm{O} 3$, Al2O3 and CaO, respectively. Several major and trace elements are accumulated at the bottom of the profiles. The accumulation of clay increases with REE contents from the upper to the lower horizons in Vertisols of Kaele area. LREE-enrichment in Vertisols is inherited from the parent material and probably preserved by the formation of secondary LREE-bearers. The low REE contents may result from depletion of REE rich minerals as in the parent rocks despite the REE remobilization during weathering. REEs how coherent geochemical behavior and low solubility during weathering. The variable Eu anomalies can be explained by the variable behavior of Eu-bearers while Ce anomalies exhibit the variability of the oxidation conditions. The low ( $\mathrm{La} / \mathrm{Yb}) \mathrm{N}$ values and the similarity of the spectra of mass balance calculation in most of the profiles are linked to the environment which is not well drained and the homogenization of the profiles by seasonal deep surficial desiccation cracks.
\end{abstract}

Keywords: North-Cameroon; Vertisols; S-type granite; Rare earth elements; Geochemistry; Mass balance evaluation

\section{Introduction}

Vertisols are dark-colored and very hard soils that develop superficial cracks which open and close periodically during moisture content variation [1]. They are rich in clay-oxyhydroxide, amongst the most fertile soils in the world at their natural state and consequently very attractive for agricultural purposes [2]. However, their physical and some of their physico-chemical properties make their agricultural exploitation very difficult [3]. This explains why their agriculture potentials have not yet been fully exploited in many parts of the world, especially in the Sub-saharan zone where widespread areas of Vertisols are either left fallow or used for grazing and wood and for charcoal burning [4].

Vertisols form under hot tropical and sub-tropical areas with contrasting climate marked by dry season and flat to gentle slopes. Mineralogically, Vertisols are characterized by a high amount of 
smectites, such as montmorillonite, beidellite and nontronite with small amounts of kaolinite, illite, quartz and feldspars [1,5]. Their CEC generally varies between 20 and $45 \mathrm{meq} / 100 \mathrm{~g}$, with exchangeable sites occupied mainly by Ca and Mg [3]. They have moderate weathering degree and $\mathrm{Si} / \mathrm{Al}$ ratio higher than 2 indicating a dominant bisiallitisation process [1]. These properties are favorable for the accumulation of REE. In fact, the abundance of clay-oxyhydroxide adsorption favors the accumulation of REE and especially LREE [6].

The behavior of Rare Earth Elements (REE) in soils and different pedological environments is poorly documented, and the different geochemical behaviors of REE need to quantify [7]. The studies concerning the geochemistry of Vertisols and particularly REE behavior are scarce [8,9]. The geochemical properties and REE behavior in Vertisols developed on sedimentary rocks have been discussed in detail by Huang and Wand [10]. The previous authors explained the variable REE behavior in different sections of sedimentary rocks by the different clay contents and clay mineral composition due to various sediments sources and sedimentary environments. However, the distribution of REE during in situ vertisol-forming process, especially Vertisols developed from richREE parent rocks, remains to be deeply examined. In such soils, formed from primary rocks, primary minerals are the main source of REE in the soils $[7,11]$. Concentrations of REE naturally found in soils depend on the parent material and typically decrease in the following order: granite $>$ basalt $>$ sandstone [12-14]. Under a dry and hot climate as in Kaele area, REE are less differentiated than their parent rocks [10].

REE are a chemically uniform group which is commonly defined as the 14 elements of the lanthanide series. Commonly, rare-earth elements with low atomic numbers are classified as Light Rare Earth Elements (LREE: La, Ce, Pr, Nd, Pm, Sm and Eu) and those with high atomic numbers are referred to Heavy Rare Earth Elements (HREE: Gd, Tb, Dy, Ho, Er, Tm, Yb and Lu) [15]. REE are used in several devices and there has been explosion in demand during the past twenty years [16]. This study reports the geochemical features of Vertisols developed on granite under contrasting seasonally variation climate in North Cameroon. It also investigates the suitability of Vertisols developed on granite as targets for REE exploration.

\section{Geographical and Geological Setting}

The study area is located in the north of Benue basin, between $10^{\circ} 00^{\prime}-10^{\circ} 30^{\prime} \mathrm{N}$ and $14^{\circ} 00^{\prime}-14^{\circ} 30^{\prime} \mathrm{E}$ (Figure 1 ) in the KaeleMindif pediplain. It is subjected to a Sudano-Sahelian climate [17] characterized by a long dry season (seven to eight months) and a short rainy season (four to five months). The mean annual rainfall and temperature in the area is $800 \mathrm{~mm}$ and $28.5^{\circ} \mathrm{C}$, respectively. The relative air humidity is low throughout the dry season (26\%) and increases significantly during the rainy season (80\%). Evapotranspiration is intense $(2685 \mathrm{~mm})$. The sunshine in the area is very strong and its average annual duration varies from 162 to $297 \mathrm{~h} /$ year [18]. The Kaele peneplain is an extension of the inselbergs located east of Mayo Louti. At an average altitude of 380 $\mathrm{m}$, the topography is generally flat with gentle slopes $<5 \%$ which limit the external drainage.

The hydrographic network is characterized by the existence of seasonal rivers. All streams are drained by temporal flows. The regime is strong in the rainy season and each rain is followed by a significant evacuation of water heavily loaded with clay, sand and gravel.

The geological substratum consists of magmatic rocks that crop out in the form of blocks in the peneplain and metamorphic rocks. The magmatic rocks are composed of calc-alkaline granites with equant grained texture and consist of feldspars (orthoclase, plagioclase), quartz, biotite, amphiboles and opaque minerals [19]. Metamorphic rocks consist of schists and gneisses (Figure 1). According to the World Reference Base for Soil Resources [20], these granites are altered to give Vertisols.

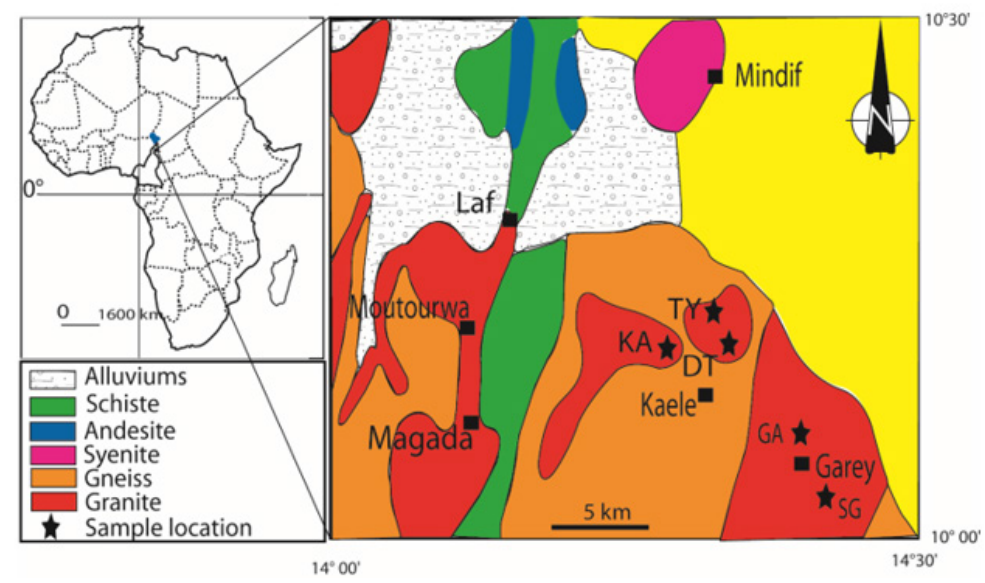

Figure 1: Geological map the study area showing sampling site locations. 


\section{Materials and Methods}

\section{Sampling and analytical methods}

Five soil profiles (SG, GA, KA, TY and DT) have been described and sampled at different depth (Figure 1). A total of 24 soil and 5 granite samples have been collected. Each rock sample represents the parent rock of a profile. Samples were collected along the profile on the basis of structure or/and color changes.

The physico-chemical analyses were done at the IITA (International Institute for Tropical Agriculture) Nkolbissong, Yaoundé. So, bulk density (Bd) was determined in reference to Archimedes' principle by pycnometer method [21]. Particle size distribution was measured by Robinsons pipette method [21]. The $\mathrm{pH}-\mathrm{H}_{2} \mathrm{O}$ was determined in a soil/water ratio of $1: 2$ and $\mathrm{pH}-\mathrm{KCl}$ in a soil/KCl ratio of 1: 2 using a glass $\mathrm{pH}$ meter [22]. The presence of carbonates was tested with dilute $\mathrm{HCl}$ solution. The organic carbon (OC) was measured by Walkley-Black procedure [23]. The organic matter was deduced from the Springel's coefficient [21]. Total nitrogen (TN) was measured by the Kjeldahl method [24]. Available phosphorus was determined by concentrated nitric acid reduction method [24]. Exchangeable cations were dosed by ammonium acetate extraction method and cation exchange capacity (CEC) was determined using the sodium saturation method [25].

Geochemical and mineralogical compositions have been determined in Geoscience Laboratories (Sudbury, Canada) and University of Rennes (France). The mineralogy was determined by $\mathrm{X}$-ray diffraction (XRD). The analytical instrument is PAN Analytical X'PERT PRO diffractometer requipped with a monochromator using a Co K $\alpha$ radiation of $1.7854 \AA$ over a range of $2.5^{\circ}$ to $35^{\circ} 2 \theta$ and a step size of $0.05^{\circ} 2 \theta / \mathrm{min}$ at $40 \mathrm{Kv}$ and $45 \mathrm{~mA}$.

Samples analyzed for major and trace elements were first crushed by a jaw crusher with steel plates and pulverized in a ball mill made of $99.8 \% \mathrm{Al}_{2} \mathrm{O}_{3}$. A two-step loss on ignition (LOI) determination was used. Powders were first heated at $105^{\circ} \mathrm{C}$ under nitrogen to drive off adsorbed water, before being ignited at 1000 ${ }^{\circ} \mathrm{C}$ under oxygen to eliminate the remaining volatiles and oxidize $\mathrm{Fe}$.

The major element concentrations were determined by X-ray Fluorescence (XRF) after sample ignition. The powder samples were first ignited then melted with a lithium tetraborate flux before analyzing with a Rigaku RIX-3000 wavelength-dispersive X-ray fluorescence spectrometer. The international reference material and the in-house reference material of the laboratory were used.

Powder rock samples were prepared by acid dilution to ensure the completed decomposition of the sample powder for the ICP-MS (Inductively Coupled Plasmas-Mass Spectrometry) analyses for trace elements concentrations by acid digestion in closed beakers [26]. They were melted with two acids $\left(\mathrm{HCl}\right.$ and $\left.\mathrm{HClO}_{4}\right)$ at 120 ${ }^{\circ} \mathrm{C}$ in sealed Teflon containers for one week; then in dilute nitric acid $\left(\mathrm{HNO}_{3}\right)$ and dried. The residue was then re-dissolved in an acid mixture $\left(\mathrm{HCl}\right.$ and $\left.\mathrm{HClO}_{4}\right)$ and dried for a second time before being dissolved in three acids $\left(\mathrm{HNO}_{3}, \mathrm{HCl}\right.$ and $\left.\mathrm{HF}\right)$ at $100{ }^{\circ} \mathrm{C}$. The instrumental precision of almost all elements was around $5 \%(2 \sigma)$ for all the compiled solutions where the elements were above the limit of quantification. Where the concentrations approached this limit, the error increased between 5 and $8.5 \%$. The solutions obtained were then analyzed using a Perkin Elmer 5000 ICP-MS spectrometer.

\section{Mass balance calculation}

Mass-balance evaluation is a set of methods that can explain the mobility of the elements during weathering processes. The most used and reliable method takes into consideration the element concentrations in different weathering samples and expresses in percentage (\%) the losses or gains. Four elements are usually used as immobile elements to evaluate gains and losses within weathered materials: Ti [27], Th [28,29], Zr [30,31] and Co [32]. Many authors agreed that stable element must be slightly accumulated in weathered material [32-34]. Titanium is the most coherent element in Vertisols of Kaele and it will be used as the immobile element. The following equation from Nesbitt and Wilson [35] and improved by Moroni et al. [36] will be applied:

$$
\% \text { change }=\left(\left(\mathrm{X}_{\mathrm{ws}} / \mathrm{Ti}_{\mathrm{ws}}\right) /\left(\mathrm{X}_{\mathrm{pr}} / \mathrm{Ti}_{\mathrm{pr}}\right)-1\right) * 100
$$

$\mathrm{X}_{\mathrm{ws}}$ and $\mathrm{X}_{\mathrm{pr}}$ are the element concentrations in the weathered sample and in the parent rock, respectively. $\mathrm{Ti}_{\mathrm{ws}}$ and $\mathrm{Ti}_{\mathrm{pr}}$ are the concentrations of the immobile element, which is Ti for this study, in the weathered sample and the parent rock, respectively.

\section{Results}

\section{Granites}

Petrography: The granite samples are dense and massive rocks with certain samples slightly weathered. The petrography of these granites has been previously presented by Nguetnkam et al. [19]. They are mainly made up of quartz, plagioclase, biotite, orthoclase, microcline and show poikilitic texture under polarized light microscope. Some accessory minerals (pyroxene, apatite, and opaque minerals) are sometimes observed. Alkali feldspar crystals are pinkish and plagioclase minerals are moulded by biotite flakes. Feldspar and especially plagioclase destabilization confirm the early stage of granite weathering.

Geochemistry: The major, trace and rare earth element contents of granite samples are presented in Table $1 . \mathrm{SiO}_{2}$ (62-75 wt.\%) and $\mathrm{Al}_{2} \mathrm{O}_{3}(12-14.73 \mathrm{wt} . \%)$ are the most abundant oxides in granites of Kaele area (Table 1$)$. They show alkali $\left(\mathrm{Na}_{2} \mathrm{O}\right.$ and $\left.\mathrm{K}_{2} \mathrm{O}\right)$ enrichment and depletion of ferromagnesian elements $\left(\mathrm{Fe}_{2} \mathrm{O}_{3}, \mathrm{MgO}\right.$, $\mathrm{MnO}$ and $\mathrm{TiO}_{2}$ ). $\mathrm{CaO}$ has a concentration higher than $3 \mathrm{wt} . \%$ in some samples (Table 1). Apart from sample TYR $\left(\mathrm{P}_{2} \mathrm{O}_{5}=4.8\right.$ wt.\%), $\mathrm{P}_{2} \mathrm{O}_{5}$ contents are very low in the granites of Kaele (Table 1). Loss on ignition (LOI) (1.3 - $4.6 \mathrm{wt} . \%)$ values confirm that some samples 
are slightly weathered. The $\mathrm{Al}_{2} \mathrm{O}_{3} / \mathrm{CaO}+\mathrm{Na}_{2} \mathrm{O}+\mathrm{K}_{2} \mathrm{O}(\mathrm{A} / \mathrm{CNK}=1.31$ 2.14) ratio values [37] reveal that these granites have peraluminous composition and belong to the S-type granites $(\mathrm{A} / \mathrm{CNK}>1.1$; Table 1).

Amongst trace elements, Sr (62 - 585 ppm), Ba (30 - 417 ppm) and $\mathrm{Zn}(11-81 \mathrm{ppm})$ have the highest contents in granites (Table 1). Zirconium, $\mathrm{Cr}$ and $\mathrm{W}$ show contrasting behavior (Table 1); samples SGR, GAR and KAR have high Zr (59 to 247 ppm), Cr (463$667 \mathrm{ppm}$ ) and W (21-31 ppm) concentrations while sample TYR, DTR and DRR possess low contents in $\operatorname{Zr}(\leq 3 \mathrm{ppm}), \mathrm{Cr}$ (3-8 ppm) and $\mathrm{W}(<1 \mathrm{ppm})$.

Table 1: Distribution of major, trace and rare-earth elements in granites.
REE concentrations in the granites are variable ranging from 24 to $191 \mathrm{ppm}$ (Table 1) with relative LREE enrichment compared to HREE $(5<$ LREE/HREE < 16). The normalized spectra relative to chondrite [38] indicate very slight lanthanide enrichments from lanthanum to samarium (Figure 2). The lanthanide normalized spectra also indicate (Figure 2 \& Table 1): (i) the presence of negative $\mathrm{Eu}$ anomalies, with $\mathrm{Eu} / \mathrm{Eu}^{*}$ ranging from 0.28 to 0.87 ; (ii) positive $\left(\mathrm{Ce} / \mathrm{Ce}^{*}=1.19-1.24\right)$ and negative $\left(\mathrm{Ce} / \mathrm{Ce}^{*}=0.66\right.$; sample TYR) Ce anomalies; (iii) and variable values of the $(\mathrm{La} / \mathrm{Yb})_{\mathrm{N}}$ ratios ranging from 4 to 20 (Table 1 ).

\begin{tabular}{|c|c|c|c|c|c|c|}
\hline \multirow[b]{2}{*}{ Symbol } & \multirow[t]{2}{*}{ d.l. } & \multicolumn{5}{|c|}{ Parent Rock (Granites) } \\
\hline & & SGR & GAR & KAR & TYR & DTR \\
\hline Depth $(\mathrm{cm})$ & & $>350$ & $>300$ & $>250$ & $>160$ & $>185$ \\
\hline SiO2 (wt.\%) & 0.01 & 73.78 & 64.57 & 71.28 & 62.28 & 65.32 \\
\hline $\mathrm{Al}_{2} \mathrm{O}_{3}$ & 0.01 & 14.73 & 15.58 & 13.95 & 16.76 & 15.97 \\
\hline $\mathrm{Fe}_{2} \mathrm{O}_{3}$ & 0.01 & 1.53 & 4.49 & 3.14 & 4.02 & 2.86 \\
\hline $\mathrm{MnO}$ & 0.01 & $<\mathrm{dl}$ & 0.04 & 0.05 & 0.01 & 0.03 \\
\hline MgO & 0.01 & 0.3 & 1.67 & 0.44 & 0.32 & 0.79 \\
\hline $\mathrm{CaO}$ & 0.01 & 3.57 & 3.81 & 1.76 & 0.17 & 3.2 \\
\hline $\mathrm{Na}_{2} \mathrm{O}$ & 0.01 & 4.09 & 3.26 & 4.12 & 6.84 & 4.61 \\
\hline $\mathrm{K}_{2} \mathrm{O}$ & 0.01 & 0.48 & 1.17 & 3.7 & 0.83 & 1.75 \\
\hline $\mathrm{TiO}_{2}$ & 0.01 & 0.08 & 0.54 & 0.29 & 0.56 & 0.36 \\
\hline $\mathrm{P}_{2} \mathrm{O}_{5}$ & 0.01 & $<\mathrm{dl}$ & 0.2 & 0.09 & 4.8 & 0.14 \\
\hline LOI & 0.01 & 1.3 & 4.6 & 1.63 & 2.94 & 4.58 \\
\hline Total & - & 99.86 & 99.93 & 100.45 & 99.52 & 99.6 \\
\hline $\mathrm{A} / \mathrm{CNK}$ & - & 1.81 & 1.89 & 1.46 & 2.14 & 1.67 \\
\hline $\mathrm{Ba}(\mathrm{ppm})$ & 0.03 & 176 & 405.8 & 416.9 & 33.57 & 78.51 \\
\hline Co & 0.004 & 3.41 & 12.67 & 4.12 & 2.13 & 5.04 \\
\hline $\mathrm{Cr}$ & 0.03 & 666.7 & 632.6 & 463 & 4.78 & 7.82 \\
\hline Cs & 0.001 & 0.22 & 0.56 & 0.58 & 0.11 & 0.18 \\
\hline $\mathrm{Cu}$ & 0.3 & 11.46 & 19.81 & 11.7 & 4.2 & 3.3 \\
\hline Ga & 0.0006 & 13.34 & 16.93 & 24.6 & 2.79 & 2.3 \\
\hline $\mathrm{Hf}$ & 0.0002 & 1.94 & 4 & 7.76 & 0.07 & 0.05 \\
\hline Mo & 0.01 & 7.24 & 6.27 & 6.27 & 0.13 & 0.28 \\
\hline $\mathrm{Nb}$ & 0.0008 & 0.86 & 4.89 & 22.42 & 0.24 & 0.24 \\
\hline $\mathrm{Ni}$ & 0.07 & 13.42 & 30.99 & 10.06 & 4.3 & 6.4 \\
\hline $\mathrm{Pb}$ & 0.02 & 4.86 & 4.97 & 13.82 & 2.45 & 5.75 \\
\hline $\mathrm{Rb}$ & 0.005 & 10.06 & 29.69 & 74.95 & 1.83 & 2.16 \\
\hline $\mathrm{Sr}$ & 0.02 & 584.6 & 561.5 & 110.4 & 187.55 & 109.8 \\
\hline Th & 0.0008 & 2.33 & 0.8 & 1.55 & 1.17 & 0.95 \\
\hline $\mathrm{U}$ & 0.0004 & 0.28 & 0.63 & 1.16 & 0.32 & 0.25 \\
\hline $\mathrm{V}$ & 0.01 & 16.81 & 77.9 & 22.47 & 12.71 & 17.17 \\
\hline $\mathrm{Y}$ & 0.0008 & 2.11 & 11.42 & 47.99 & 12.71 & 5.35 \\
\hline W & 0.002 & 30.66 & 27.23 & 21 & 0.03 & 0.06 \\
\hline
\end{tabular}




\begin{tabular}{|c|c|c|c|c|c|c|}
\hline $\mathrm{Zn}$ & 0.9 & 11.29 & 55.36 & 80.98 & 22.5 & 64.4 \\
\hline $\mathrm{Zr}$ & 0.002 & 59.83 & 157.9 & 246.3 & 2.84 & 3 \\
\hline Sn & 0.03 & 1.95 & 2.37 & 3.4 & 0.24 & 0.25 \\
\hline $\mathrm{La}(\mathrm{ppm})$ & 0.1 & 4.41 & 11.31 & 32.33 & 15.48 & 11.15 \\
\hline $\mathrm{Ce}$ & 0.12 & 11.64 & 23.42 & 75.75 & 21.22 & 29.13 \\
\hline $\operatorname{Pr}$ & 0.014 & 1.19 & 3.14 & 9.07 & 3.93 & 3.19 \\
\hline $\mathrm{Nd}$ & 0.06 & 4.53 & 12.64 & 35.34 & 14.83 & 12.62 \\
\hline $\mathrm{Sm}$ & 0.026 & 0.85 & 2.67 & 8.03 & 2.47 & 2.09 \\
\hline $\mathrm{Eu}$ & 0.0031 & 0.1 & 0.23 & 0.89 & 0.51 & 0.5 \\
\hline $\mathrm{Gd}$ & 0.009 & 0.61 & 2.26 & 7.31 & 1.73 & 1.42 \\
\hline $\mathrm{Tb}$ & 0.023 & 0.07 & 0.32 & 1.28 & 0.23 & 0.18 \\
\hline Ho & 0.009 & 0.07 & 0.37 & 1.54 & 0.25 & 0.19 \\
\hline Dy & 0.0025 & 0.37 & 1.97 & 7.87 & 1.32 & 0.99 \\
\hline Er & 0.007 & 0.21 & 1.07 & 4.78 & 0.65 & 0.51 \\
\hline $\mathrm{Tm}$ & 0.019 & 0.03 & 0.15 & 0.73 & 0.09 & 0.07 \\
\hline $\mathrm{Yb}$ & 0.009 & 0.22 & 1.1 & 4.93 & 0.53 & 0.42 \\
\hline $\mathrm{Lu}$ & 0.02 & 0.04 & 0.17 & 0.74 & 0.07 & 0.06 \\
\hline REE & - & 24.35 & 60.82 & 190.59 & 63.31 & 62.52 \\
\hline LREE & - & 22.72 & 53.41 & 161.42 & 58.44 & 58.68 \\
\hline HREE & - & 1.63 & 7.41 & 29.17 & 4.87 & 3.84 \\
\hline LREE/HREE & - & 13.92 & 7.21 & 5.53 & 12 & 15.28 \\
\hline $\mathrm{Ce} / \mathrm{Ce}^{*}$ & - & 1.24 & 0.96 & 1.08 & 0.66 & 1.19 \\
\hline $\mathrm{Eu} / \mathrm{Eu}^{*}$ & - & 0.42 & 0.28 & 0.35 & 0.74 & 0.87 \\
\hline$(\mathrm{La} / \mathrm{Yb})_{\mathrm{N}}$ & - & 13.83 & 7.04 & 4.5 & 20.04 & 18.21 \\
\hline
\end{tabular}

d.I.: Detection limit.

LOI: Loss on ignition.

$\mathrm{A} / \mathrm{CNK}=\mathrm{Al}_{2} \mathrm{O}_{3} / \mathrm{CaO}+\mathrm{Na}_{2} \mathrm{O}+\mathrm{K}_{2} \mathrm{O}$.

$\mathrm{Ce} / \mathrm{Ce}^{*}:\left(\mathrm{Ce}_{\text {granite }} / \mathrm{Ce}_{\text {chondrite }}\right) /\left(\mathrm{La}_{\text {granite }} / \mathrm{La}_{\text {chondrite }}\right)^{1 / 2}\left(\mathrm{Pr}_{\text {granite }} / \mathrm{Pr}_{\text {chondrite }}\right)^{1 / 2}$.

$\mathrm{Eu} / \mathrm{Eu}^{*}:\left(\mathrm{Eu}_{\text {granite }} / \mathrm{Eu}_{\text {chondrite }}\right) /\left(\mathrm{Sm}_{\text {granite }} / \mathrm{Sm}_{\text {chondrite }}\right)^{1 / 2}\left(\mathrm{Gd}_{\text {granite }} / \mathrm{Gd}_{\text {chondrite }}\right)^{1 / 2}$.

$(\mathrm{La} / \mathrm{Yb})_{\mathrm{N}}:\left(\mathrm{La}_{\text {granite }} / \mathrm{La}_{\text {chondrite }}\right) /\left(\mathrm{Yb}_{\text {granite }} / \mathrm{Yb}_{\text {chondrite }}\right)$.

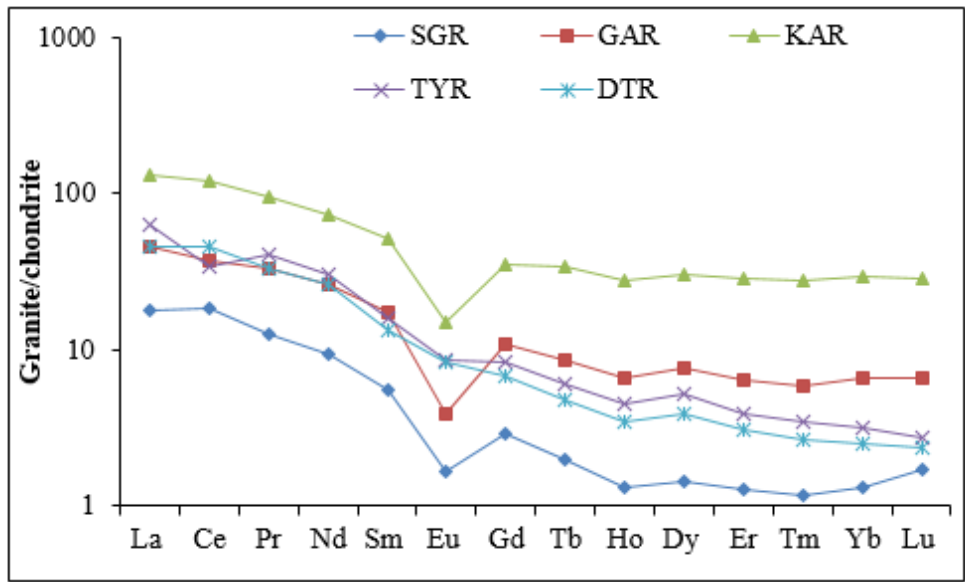

Figure 2: Geological map the study area showing sampling site locations. 


\section{Vertisols}

\section{Soil profile descriptions}

Profile SG: Profile SG is described in Garey 1 located between 10
${ }^{\circ} 01^{\prime} 52^{\prime \prime} \mathrm{N}$ and $14^{\circ} 19^{\prime} 36^{\prime \prime} \mathrm{E}$. The profile is located at $378 \mathrm{~m}$ altitude. On the surface, a gilgai "microrelief" with unevenness of the order of $50 \mathrm{~cm}$ develops there. The $4 \mathrm{~m}$ thick soil rests on granite whose alteration is significant. From top to bottom, we observe (Figure 3).

\begin{tabular}{|c|c|c|}
\hline Horizon & Depth (cm) & \\
\hline $\mathrm{A} 1$ & $0-30$ & $\begin{array}{l}\text { black (10 YR 2/1); dry; silty clay; organic matter not directly detectable; fine, very distinct subangular polyhedral structure; } \\
\text { fairly large void volume between the aggregates, aggregates with few pores, very fine, not very porous horizon; material } \\
\text { with semi-rigid consistency, not very fragile, plastic, not very sticky in the wet state; many fine roots between the aggre- } \\
\text { gates; regular transition. }\end{array}$ \\
\hline $\mathrm{A} 2$ & $30-100$ & $\begin{array}{l}\text { black (10 YR 2/0.5); dry; clay; organic matter not directly detectable; medium to coarse subangular polyhedral structure } \\
\text { with very clear prismatic structure; low void volumes between aggregates, consistent, } 1 \text { to } 2 \mathrm{~cm} \text { wide and } 20 \mathrm{~cm} \text { distance } \\
\text { recesses, few pore aggregates, thin, tubular; not very porous; rigid, non-brittle, plastic, sticky material; many fine roots } \\
\text { between the aggregates; gradual and regular transition. }\end{array}$ \\
\hline Bss & $100-200$ & $\begin{array}{l}\text { Dark gray to black (5 YR 2.5/1); fresh; clay; few sparse spots, dark brown (7.5 YR 3/2), irregular, with sharp boundaries, } \\
\text { very contrasting, sizes of } 1 \mathrm{~mm} \text {; organic matter not directly detectable; prismatic structure, with very distinct oblique plate- } \\
\text { let structure; low void volumes between aggregates, consistent, no shrinkage slots, aggregates without visible pores, very } \\
\text { little porous; presence of slikensides; material with malleable consistency, very plastic, very sticky, non-friable; some fine } \\
\text { roots between the aggregates; gradual and regular transition. }\end{array}$ \\
\hline Bck & $200-300$ & $\begin{array}{l}\text { Dark gray (5 YR 2.5/1); fresh; without stains; organic matter not directly detectable; clay; prismatic structure, with very } \\
\text { distinct oblique platelet structure; generalized effervescence, } 2 \text { to } 5 \% \text { of carbonate elements in nodule (1 to } 2 \text { mm in diame- } \\
\text { ter); very low void volume between aggregates, consistent, with no visible pores; very little porous; presence of slikensides; } \\
\text { material with malleable consistency, plastic, very sticky, non-friable; no root; gradual and regular transition. }\end{array}$ \\
\hline $\mathrm{C}$ & $300-350$ & $\begin{array}{l}\text { Gray (2.5 YR 3.5/3); clay-sandy; coarse, clean polyhedral structure; very low void volume between aggregates, aggregates } \\
\text { without visible pores, consistent; very little porous; material with a semi-rigid consistency, non-friable and not very sticky; } \\
\text { no roots; gradual transition with the source rock (granite). }\end{array}$ \\
\hline $\mathrm{R}$ & $350-400$ & Parent granite comprising Na-rich plagioclase, K-feldspar, quartz, biotite and amphibole. \\
\hline
\end{tabular}

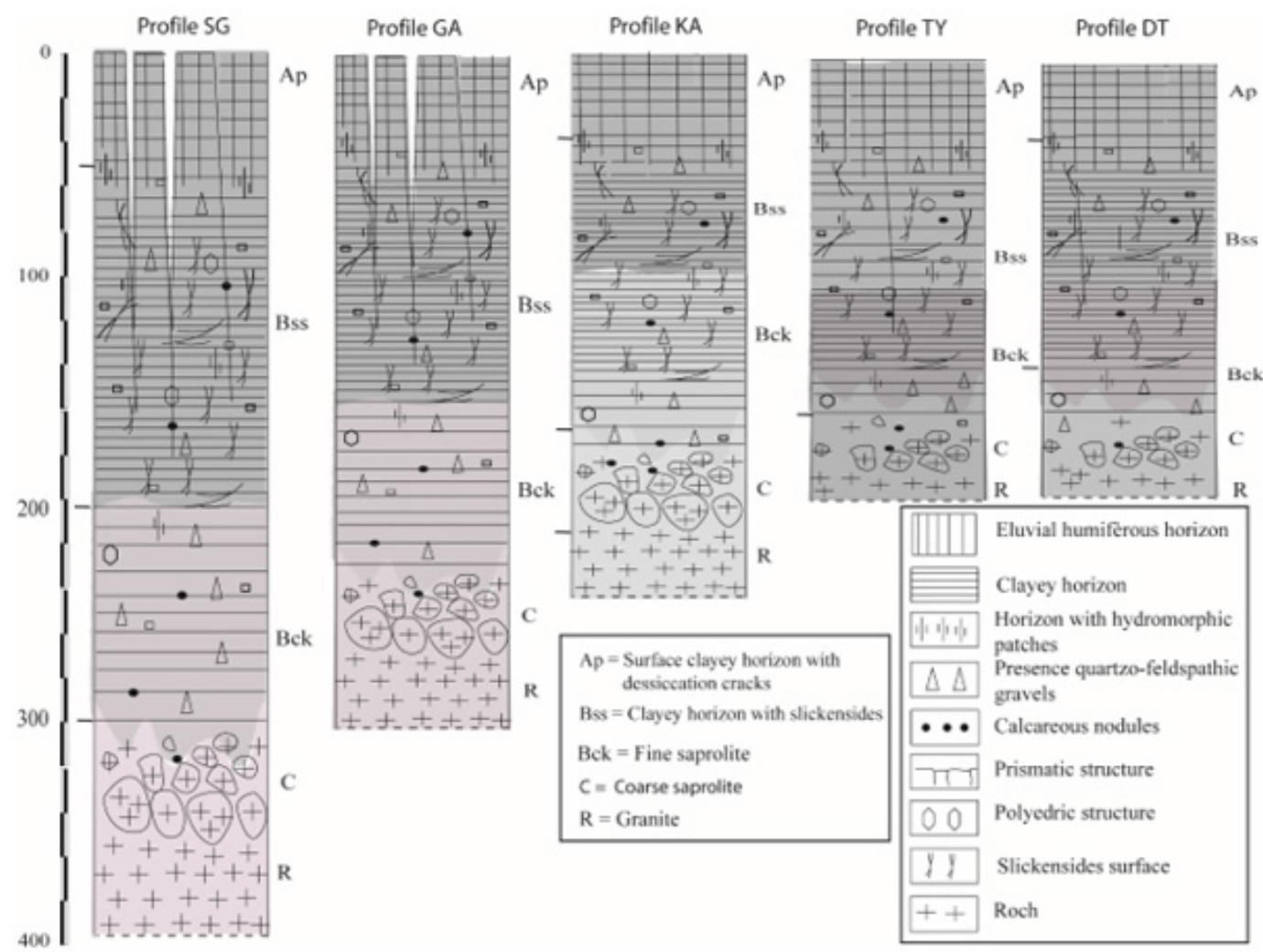

Figure 3: Representative weathering profile description of Vertisols developed on granite of Kaele area (GA profile). 
Profile GA: Profile GA was implanted at Garey 2 on latitude $10^{\circ} 02^{\prime} 02^{\prime \prime} \mathrm{N}$, longitude $14^{\circ} 20^{\prime} 27^{\prime \prime} \mathrm{E}$ and an altitude of $373 \mathrm{~m}$, on a sub-horizontal to flat plain whose gradient was about $0.3 \%$. The land use was for sorghum cultivation without irrigation. This profile was limited at $3 \mathrm{~m}$ depth. It showed three horizons above the roch table which included the Bck $(210-110 \mathrm{~cm})$ horizon, the Bss $(40-110 \mathrm{~cm})$ horizon and the Ap $(0-40 \mathrm{~cm})$ horizon (Figure 3).
Those horizons were morphologically identical to those of SG.

Profile KA: Profile KA was dug at the East of Kaele on latitude $10^{\circ} 06^{\prime} 39^{\prime \prime} \mathrm{N}$, longitude $14^{\circ} 25^{\prime} 41^{\prime \prime} \mathrm{E}$ and an elevation of $381 \mathrm{~m}$. Slope gradient was $0.6 \%$, current land use was for sorghum cultivation. This pit was limited at $2.5 \mathrm{~m}$ depth above the granite and presented four main horizons, which include from bottom to top (Figure 3).

\begin{tabular}{|c|c|c|}
\hline Horizon & Depth (cm) & \\
\hline Ap & $0-90$ & $\begin{array}{l}\text { black (10 YR 2/1); dry; organic matter not directly detectable; silty-clay; fine, very distinct subangular polyhedral structure; } \\
\text { fairly large void volume between the aggregates, aggregates with few pores, very fine, not very porous horizon; material } \\
\text { with semi-rigid consistency, not very fragile, not very plastic, not very sticky in the wet state; many fine roots between the } \\
\text { aggregates; regular transition. }\end{array}$ \\
\hline Bss & $90-120$ & $\begin{array}{l}\text { Dark gray to black (5 YR 2.5/1); fresh; few sparse spots, dark brown (7.5 YR 3/2), irregular, with sharp boundaries, very } \\
\text { contrasting, sizes of } 1 \mathrm{~mm} \text {; organic matter not directly detectable; clay; prismatic structure, with very distinct oblique } \\
\text { platelet structure; low void volumes between aggregates, consistent, no shrinkage slots, aggregates without visible pores, } \\
\text { very little porous; presence of slikensides; material with malleable consistency, very plastic, very sticky, non-friable; some } \\
\text { fine roots between the aggregates; gradual and regular transition. }\end{array}$ \\
\hline Bck & $120-200$ & $\begin{array}{l}\text { Dark gray (5 YR 2.5/1); fresh; without stains; organic matter not directly detectable; clay; prismatic structure, with very } \\
\text { distinct oblique platelet structure; generalized effervescence, } 2 \text { to } 5 \% \text { of carbonate elements in nodule (1 to } 2 \text { mm in diame- } \\
\text { ter); very low void volume between aggregates, consistent, with no visible pores; very little porous; presence of slikensides; } \\
\text { material with malleable consistency, plastic, very sticky, non-friable; no root; gradual and regular transition. }\end{array}$ \\
\hline $\mathrm{C}$ & $200-250$ & $\begin{array}{l}\text { Gray (2.5 YR 3.5/3); clay-sandy; coarse, clean polyhedral structure; very low void volume between aggregates, aggregates } \\
\text { without visible pores, consistent; very little porous; material with a semi-rigid consistency, non-friable and not very sticky; } \\
\text { no roots; gradual transition with the source rock (granite). }\end{array}$ \\
\hline $\mathrm{R}$ & $>250$ & Parent granite comprising Na-rich plagioclase, K-feldspar, quartz, biotite and amphibole. \\
\hline
\end{tabular}

Profile TY: The profile of TY has the geographic coordinates of latitude $10^{\circ} 05^{\prime} 25^{\prime \prime} \mathrm{N}$, longitude $14^{\circ} 25^{\prime} 42^{\prime \prime} \mathrm{E}$ and an elevation of 392 $\mathrm{m}$. He has one thickness of $160 \mathrm{~cm}$. On the surface, we can notice the shrinkage or desiccation slits ( 5 to $15 \mathrm{~cm}$ deep and 1 to $2 \mathrm{~cm}$ wide). From top to bottom, we observe (Figure 3):

\begin{tabular}{|c|c|c|}
\hline Horizon & Depth (cm) & \\
\hline Ap & $0-80$ & $\begin{array}{l}\text { Light gray, } 10 \text { YR- } 8 / 2 \text { with a blocky and silty-clayey-sandy structure, presence of rust spots and coarse elements of } \\
\text { angular shape, not very porous, compact and friable in the dry state. The transition is gradual with the underlying } \\
\text { horizon; }\end{array}$ \\
\hline Bss & $80-130$ & $\begin{array}{l}\text { Dark gray, } 7.5 \text { YR- } 6 / 2 \text {, sandy clay, prismatic structure, abundance of grains of quartz, micas and weathered feldspar; } \\
\text { presence of rust spots, not very porous, not very friable. The transition is gradual with the underlying horizon; }\end{array}$ \\
\hline Bck & $130-160$ & $\begin{array}{l}\text { Dark gray, 10YR-4/1 blocky, silty-sandy, traces of roots, presence of unaltered minerals and crumbly calcareous nod- } \\
\text { ules. }\end{array}$ \\
\hline
\end{tabular}

Profile DT: Profile DT was implanted on a Vertisols field at Djidoma Dardo (latitude $10^{\circ} 05^{\prime} 34^{\prime \prime} \mathrm{N}$, longitude $13^{\circ} 20^{\prime} 59^{\prime \prime} \mathrm{E}$ and altitude $382 \mathrm{~m}$ ) at about $25 \mathrm{~km}$ SE of Kaele which serves for rice cultivation. The opened $2 \mathrm{~m}$ deep profile, limited by a marshy layer, was morphologically very similar to the other previously described profiles (Figure 3). In this site, Vertisols shows different surface features depending on whether it occurs in areas with opened depressions or not. In the opened depressions where some surface drainage is possible, the surface horizon is mainly covered by earthworm casts.

\section{Morphology and mineralogy}

Vertisols profiles described were characterized by a dark color, a heavy clayey texture, massive structure, low porosity, high compacity and deep open surficial desiccation cracks, but also by the development of frictional surfaces (slickensides) in the middle part of the profile. The weathering sequence of Vertisols can be classified into granite (R and C); Bck horizon; (iii) Bss horizon; and

\section{Ap horizon (Figure 3).}

The granite arena is clear, slightly moist, fine to medium grained, speckled with brown streaks. The structure of the granite is preserved and composed mainly of secondary minerals like beidellite, montmorillonite and kaolinite. Primary minerals like biotite, amphibole, calcite and dolomite are rare. The granite architecture is not preserved in the Bck horizon which is mainly composed of beidellite. Bss horizon is composed of a melt of dark grey clay materials, and relics of saprolitic domains as well as calcareous nodules. This horizon possesses the highest clay content and slickenside in which beidellite is associated with few amounts of montmorillonite and kaolinite. Ap horizon is dark grey, clayrich, and exhibits a strong coarse angular blocky structure with calcareous nodules. Desiccation cracks are present at the surface. The horizon is made up of beidellite, montmorillonite, kaolinite with small amount of quartz. A statistical summary of physicchemical properties of the soils is given in Table 2. 
Table 2: Statistical summary of some physico-chemical properties of Vertisols.

\begin{tabular}{|c|c|c|c|c|}
\hline Soil Property $(n=35)$ & Mean & Max & Min & SD \\
\hline \multicolumn{5}{|c|}{ Physical Properties } \\
\hline Clay $(<2 \mu \mathrm{m}),(\%)$ & 27.26 & 48 & 7.62 & 12.02 \\
\hline Silt $(2-50 \mu \mathrm{m}),(\%)$ & 22.74 & 36.24 & 6.35 & 6.84 \\
\hline Sand $(50-200 \mu \mathrm{m}),(\%)$ & 48.46 & 86.02 & 18 & 16.18 \\
\hline Bulk density, $\left(\mathrm{mg} \mathrm{m}^{-3}\right)$ & 1.95 & 2.1 & 1.7 & 0.25 \\
\hline \multicolumn{5}{|c|}{ Chemical Properties } \\
\hline $\mathrm{pH}\left(1: 1 \mathrm{H}_{2} \mathrm{O}\right)$ & 8.09 & 9.7 & 6.75 & 1.2 \\
\hline $\mathrm{pH}(\mathrm{KCl})$ & 6.63 & 7.6 & 5.57 & 0.73 \\
\hline Carbon organic, $\left(\mathrm{g} \mathrm{kg}^{-1}\right)$ & 1.92 & 3.52 & 0.77 & 0.76 \\
\hline Organic matter, $\left(\mathrm{g} \mathrm{kg}^{-1}\right)$ & 3.6 & 7.08 & 1.33 & 1.65 \\
\hline Total Nitrogen, $\left(\mathrm{g} \mathrm{kg}^{-1}\right)$ & 0.38 & 0.59 & 0.13 & 0.12 \\
\hline Available $\mathrm{P},\left(\mathrm{g} \mathrm{kg}^{-1}\right)$ & - & - & - & - \\
\hline Exchangeable $\mathrm{Ca}^{2+},\left(\mathrm{cmol} \mathrm{kg}^{-1}\right)$ & 4.29 & 15.08 & 0.2 & 5.6 \\
\hline Exchangeable $\mathrm{Mg}^{2+},\left(\mathrm{cmol} \mathrm{kg}^{-1}\right)$ & 15.23 & 54.45 & 1.12 & 14.52 \\
\hline Exchangeable $\mathrm{Na}^{+},\left(\mathrm{cmol} \mathrm{kg}^{-1}\right)$ & 0.11 & 0.61 & 0.04 & 0.17 \\
\hline Exchangeable $\mathrm{K}^{+},\left(\mathrm{cmol} \mathrm{kg}^{-1}\right)$ & 0.07 & 0.84 & 0.15 & 0.24 \\
\hline Base saturation (\%) & 19.84 & 57.77 & 7.65 & 12.05 \\
\hline $\mathrm{CEC},\left(\mathrm{cmol} \mathrm{kg}^{-1}\right)$ & 23.84 & 39.84 & 12.8 & 7.68 \\
\hline $\mathrm{C} / \mathrm{N}$ & 5.43 & 8.8 & 0.48 & 2.67 \\
\hline $\mathrm{S} / \mathrm{CEC}$ & 80.65 & 267.4 & 0.36 & 66.92 \\
\hline \multicolumn{5}{|c|}{ Mineralogical Properties } \\
\hline Smectites (Sm) & 53.99 & 100 & 24.6 & 23.99 \\
\hline Kaolinite (Kao) & 10.35 & 30.44 & 2.18 & 6.38 \\
\hline Kao-Sm & 24.3 & 45.87 & 0 & 16.06 \\
\hline Quartz (Q) & 11.94 & 28.86 & 4 & 6.92 \\
\hline Feldspar (Fe) & 3.12 & 7.15 & 1.06 & 2.75 \\
\hline
\end{tabular}

\section{Geochemistry}

As for parent rocks, $\mathrm{SiO}_{2}$ and $\mathrm{Al}_{2} \mathrm{O}_{3}$ are the dominant major elements in the weathered samples (Table 3). The alkali $\left(\mathrm{Na}_{2} \mathrm{O}\right.$ and $\mathrm{K}_{2} \mathrm{O}$ ) as well as the ferromagnesian elements such as $\mathrm{Fe}_{2} \mathrm{O}_{3}$ and $\mathrm{MgO}$ have significant concentrations in the Vertisols of Kaele (Table 3). The other ferromagnesian elements ( $\mathrm{MnO}$ and $\mathrm{TiO}_{2}$ ) have low contents but higher than the detection limit. Losses on ignition (LOI) and $\mathrm{CaO}$ have significant values in Vertisols of Kaele. $\mathrm{P}_{2} \mathrm{O}_{5}$ has low contents especially in KA profile. TY Profile has the highest $\mathrm{P}_{2} \mathrm{O}_{5}$ contents up to 4 wt.\% (Table 3). The Harker diagrams indicate slight negative correlations between $\mathrm{Si}$ and $\mathrm{Al}, \mathrm{Fe}, \mathrm{Mg}$ and Ca (Figures $4 \mathrm{a}-\mathrm{d})$. The alkali $\left(\mathrm{Na}_{2} \mathrm{O}\right.$ and $\left.\mathrm{K}_{2} \mathrm{O}\right)$ show no correlation with silica (Figures $4 \mathrm{e} \& \mathrm{f}$ ).

Trace elements that have high contents in Vertisols of Kaele are $\mathrm{Sr}, \mathrm{Ba}, \mathrm{Cr}, \mathrm{Zr}$ and $\mathrm{Zn}$ (Table 4). These elements have the highest contents in SG, GA and KA profiles while the lowest values are registered in TY and DT profiles. On contrary to the parent rocks, trace elements such as $\mathrm{Co}, \mathrm{Cu}, \mathrm{Rb}$ and $\mathrm{V}$ have significant contents in weathered product (Table 4). 


\begin{tabular}{|c|c|c|c|c|c|c|c|c|c|c|c|c|c|}
\hline$\vec{E}$ & 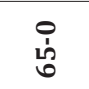 & $\begin{array}{l}\text { th } \\
\text { th. } \\
\text { : }\end{array}$ & 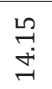 & $\stackrel{g}{\circ}$ & of & $\begin{array}{l}\infty \\
\stackrel{\infty}{0} \\
0\end{array}$ & 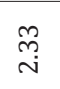 & $\underset{\sim}{\stackrel{N}{N}}$ & g. & $\stackrel{\substack{0 \\
o}}{o}$ & $\hat{o}$ & $\underset{\infty}{\stackrel{P}{+}}$ & $\sigma \stackrel{2}{m}$ \\
\hline 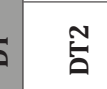 & 岗 டூ & 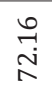 & $\stackrel{\text { }}{\text { İ }}$ & 怘 & $\hat{o}$ & $\stackrel{P}{\leftarrow}$ & 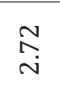 & $\tilde{\dot{m}}$ & g. & กิ & $\stackrel{\circ}{\circ}$ & $\stackrel{\stackrel{L}{m}}{\underset{+}{+}}$ & Sू \\
\hline$\stackrel{m}{G}$ & 官 & $\begin{array}{l}\hat{\infty} \\
\stackrel{0}{R} \\
\end{array}$ & $\stackrel{+}{\stackrel{+}{త}}$ & 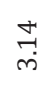 & $\hat{o}$ & ָָ & $\underset{\stackrel{\sim}{N}}{\stackrel{\sim}{N}}$ & $\begin{array}{l}\stackrel{\bullet}{\circ} \\
\stackrel{i}{N}\end{array}$ & $\begin{array}{l}\stackrel{0}{\infty} \\
\stackrel{0}{0}\end{array}$ & 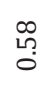 & $\stackrel{1}{0}$ & 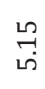 & ğ \\
\hline$\vec{Z}$ & $\begin{array}{l}\dot{1} \\
\dot{j}\end{array}$ & 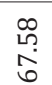 & $\begin{array}{l}\stackrel{\infty}{ } \\
\stackrel{\leftrightarrow}{\sim}\end{array}$ & $\underset{\sim}{\tilde{N}}$ & $\begin{array}{l}\overrightarrow{0} \\
0\end{array}$ & So & $\overrightarrow{7}$ & 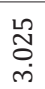 & 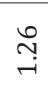 & 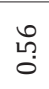 & 卓 & L & Б̊ \\
\hline
\end{tabular}

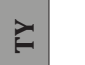

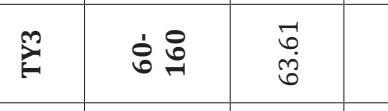

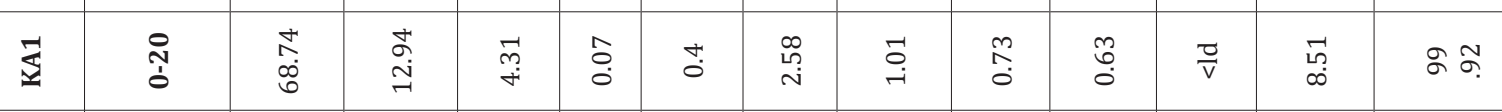

\begin{tabular}{|c|c|c|}
\hline$\tilde{\Sigma}$ & ก่่̊ & $\underset{\vec{b}}{\overrightarrow{0}}$ \\
\hline
\end{tabular}

$\Xi$

\begin{tabular}{|c|c|c|c|c|c|c|c|c|c|c|c|c|}
\hline$\stackrel{m}{\Sigma}$ & \&̊워 & $\begin{array}{l}\overrightarrow{7} \\
\text { हु. }\end{array}$ & 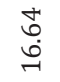 & 菅 & $\stackrel{\circ}{\circ}$ & $\stackrel{\circ}{\circ}$ & 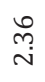 & & $\stackrel{\overrightarrow{0}}{\circ}$ & : & $\overline{\vec{v}}$ & $\stackrel{m}{\sigma}$ \\
\hline$\underset{\$}{ \pm}$ & ิํํ : & 官 & $\begin{array}{l}\hat{\sigma} \\
\stackrel{\text { i }}{1}\end{array}$ & 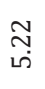 & 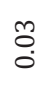 & นี & 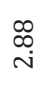 & 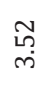 & $\begin{array}{l}\stackrel{+}{\infty} \\
0 \\
0\end{array}$ & 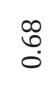 & ô. & ${ }_{\infty}^{0}$ \\
\hline 10 & $\dot{0}$ & $\infty$ & $\stackrel{\infty}{n}$ & $=$ & $\stackrel{2}{\circ}$ & శె & $\stackrel{\infty}{\infty}$ & $\exists$ & & & $=$ & $\approx$ \\
\hline
\end{tabular}

\begin{tabular}{|c|c|c|c|c|c|c|c|c|c|c|c|c|c|}
\hline 适 & 穴 & 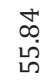 & $\begin{array}{l}\stackrel{\infty}{\stackrel{D}{N}} \\
\stackrel{N}{N}\end{array}$ & Fे & $\stackrel{\text { L̊ }}{0}$ & $\begin{array}{l}\text { ?ִ } \\
0\end{array}$ & 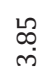 & $\overrightarrow{\text { Fे }}$ & $\stackrel{t}{\Delta}$ & $\stackrel{0}{\circ}$ & ने & స్ & S๐ \\
\hline స్తુ & $\stackrel{\text { ก̀ }}{\text { ò }}$ & $\stackrel{\stackrel{N}{ }}{\stackrel{N}{N}}$ & 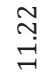 & $\stackrel{\circ}{\stackrel{f}{+}}$ & $\hat{o}_{0}^{\circ}$ & $\begin{array}{l}\infty \\
\stackrel{0}{0} \\
\stackrel{0}{0}\end{array}$ & & $\begin{array}{c}\substack{\infty \\
\text { นִ } \\
0} \\
0\end{array}$ & 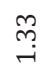 & $\hat{o}$ & : & 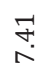 & ๙ே \\
\hline
\end{tabular}

\begin{tabular}{|c|c|c|c|c|c|c|c|c|c|c|c|c|c|c|}
\hline & J్ & 孞 & $\begin{array}{l}\text { 오. } \\
\text { هి }\end{array}$ & مे & $\stackrel{\circ}{+}$ & ô. & $\stackrel{\infty}{0}$ & $\underset{\sim}{\stackrel{\sim}{*}}$ & $\begin{array}{l}\infty \\
\stackrel{0}{0} \\
0\end{array}$ & $\stackrel{\infty}{\stackrel{\oplus}{\rightarrow}}$ & 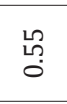 & $\stackrel{20}{\stackrel{0}{0}}$ & $\underset{\infty}{F}$ & Sूt \\
\hline \multirow{6}{*}{ w } & ్ָ & ì & $\begin{array}{l}0 \\
\text { m. } \\
\stackrel{0}{0}\end{array}$ & $\stackrel{\stackrel{L}{N}}{\underset{\sim}{N}}$ & $\underset{\stackrel{H}{H}}{\stackrel{H}{S}}$ & o̊ & $\begin{array}{l}\infty \\
\substack{\infty \\
0 \\
0}\end{array}$ & 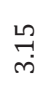 & 今̂ & $\underset{\sim}{\stackrel{N}{H}}$ & $\stackrel{N}{\stackrel{0}{0}}$ & $\stackrel{0}{\circ}$ & $\hat{o}$ & ริ sิ \\
\hline & $\mathscr{g}$ & 훌워 & 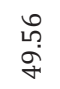 & 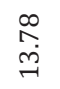 & $\begin{array}{l}\stackrel{0}{m} \\
\text { in }\end{array}$ & o̊. & 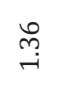 & $\approx$ & $\underset{\sim}{\stackrel{\sim}{\sim}}$ & $\underset{+}{\stackrel{H}{+}}$ & $\stackrel{+}{\Delta}$ & Эิㅜㅇ & $\underset{\sim}{\hat{m}}$ & 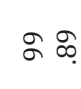 \\
\hline & 离 & ثิ่ & $\begin{array}{l}\infty \\
\infty \\
\text { id } \\
\text { h. }\end{array}$ & $\begin{array}{l}\text { मे } \\
\stackrel{5}{7}\end{array}$ & $\stackrel{H}{\stackrel{H}{N}}$ & F. & $\stackrel{\leftrightarrow}{\vec{r}}$ & $\vec{\sigma}$ & 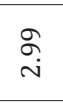 & $\stackrel{\overbrace{}}{\vec{H}}$ & $\begin{array}{l}0 \\
\stackrel{0}{0}\end{array}$ & 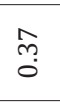 & $\stackrel{\widehat{m}}{N}$ & ब \\
\hline & 总 & 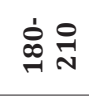 & $\begin{array}{l}\stackrel{2}{0} \\
8 \\
0\end{array}$ & $\stackrel{2}{\sim}$ & 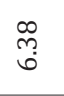 & $\begin{array}{l}\infty \\
\stackrel{0}{0}\end{array}$ & $\stackrel{\infty}{\stackrel{\infty}{i}}$ & 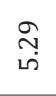 & 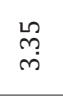 & $\stackrel{\infty}{\rightarrow}$ & 총 & ঙ̊. & $\begin{array}{l}\stackrel{0}{L} \\
\stackrel{\text { m }}{n}\end{array}$ & Sू \\
\hline & 岂 & ㅎํㅇ & $\stackrel{+}{\stackrel{D}{n}}$ & 忞 & $\underset{\infty}{\stackrel{f}{0}}$ & $\overrightarrow{7}$ & $\stackrel{\sim}{\stackrel{N}{N}}$ & ָָ & $\underset{\dot{q}}{\stackrel{q}{r}}$ & $\stackrel{\sim}{\rightarrow}$ & $\stackrel{m}{\rightarrow}$ & Iี & $\begin{array}{l}\tilde{m} \\
\text { i. }\end{array}$ & જूs. \\
\hline & $\hat{心}$ & 寅号 & $\begin{array}{l}+ \\
\infty \\
\infty \\
\infty \\
i n\end{array}$ & 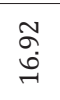 & 占 & F & $\stackrel{\circ}{\stackrel{\circ}{i}}$ & $\begin{array}{l}\stackrel{\vartheta}{\hat{L}} \\
\text { i. }\end{array}$ & $\overrightarrow{\tilde{n}}$ & $\stackrel{\sim}{\sim}$ & $\vec{\sigma}$ & $\vec{m}$ & $\vec{m}$ & $\stackrel{0}{\rightarrow}$ \\
\hline تं & & & $\stackrel{5}{0}$ & $\stackrel{\sigma}{0}$ & $\ddot{0}$ & ¿j & $\ddot{\circ}$ & $\begin{array}{l}\overrightarrow{0} \\
0\end{array}$ & $\stackrel{\overrightarrow{0}}{0}$ & $\stackrel{\sigma}{0}$ & $\stackrel{\sigma}{0}$ & $\ddot{\circ}$ & $\stackrel{\sigma}{0}$ & . \\
\hline 号 & & & $0^{N}$ & $\stackrel{0^{m}}{\overbrace{}^{m}}$ & $\begin{array}{l}O^{\infty} \\
\sigma^{N}\end{array}$ & ஓ & $\stackrel{\circ}{\sum_{2}^{\infty}}$ & ఊ్ర & $\begin{array}{l}0 \\
\tilde{z}^{N}\end{array}$ & $\begin{array}{l}0 \\
x^{N}\end{array}$ & 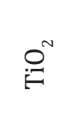 & $\begin{array}{l}0^{n n} \\
\Omega^{n}\end{array}$ & ō & $\begin{array}{l}\overrightarrow{\mathrm{J}} \\
\stackrel{0}{\circ}\end{array}$ \\
\hline
\end{tabular}




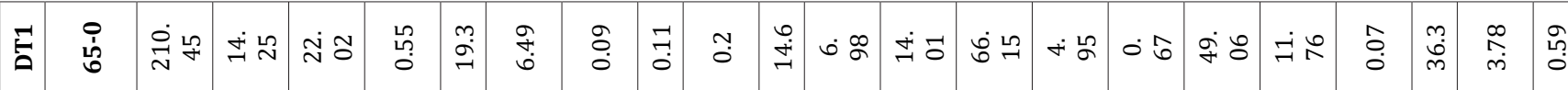

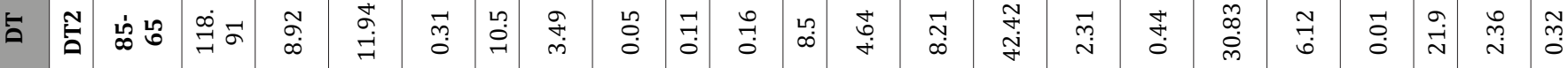

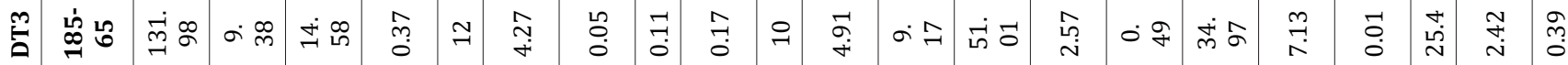

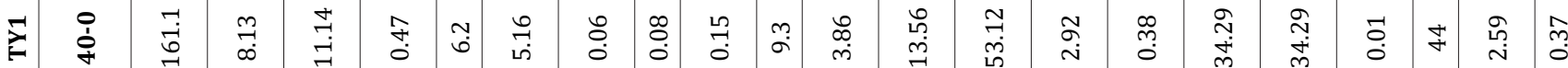

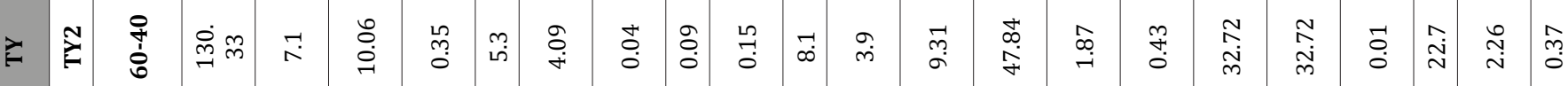

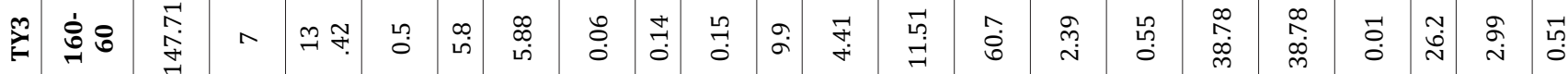

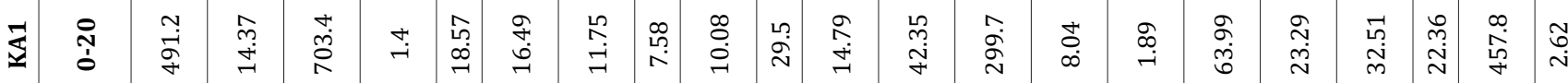

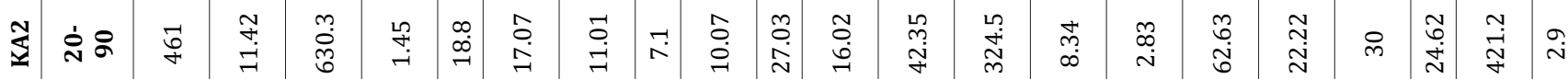

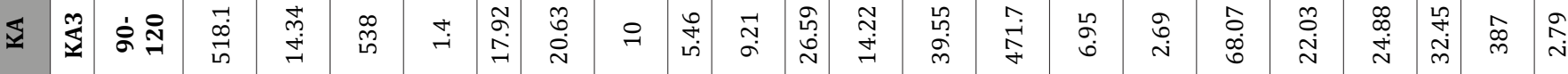

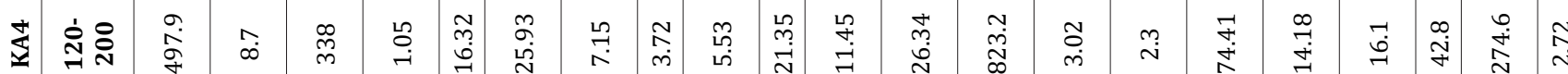

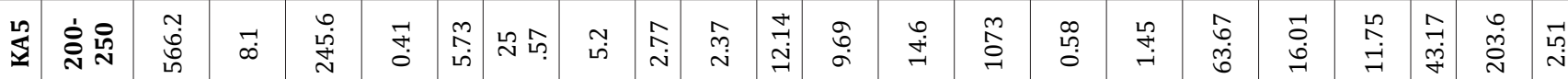

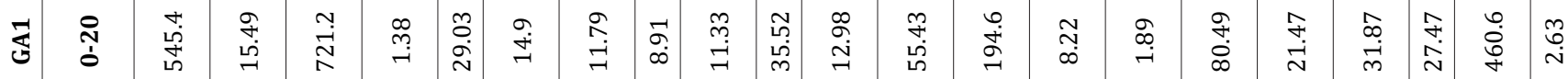

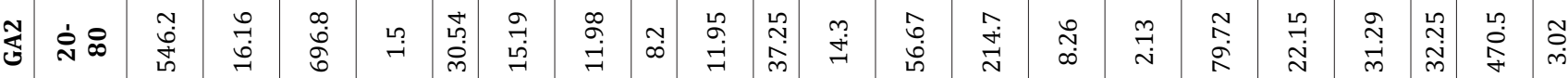

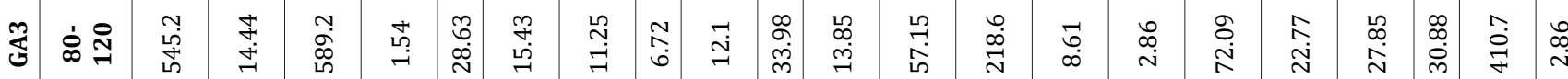

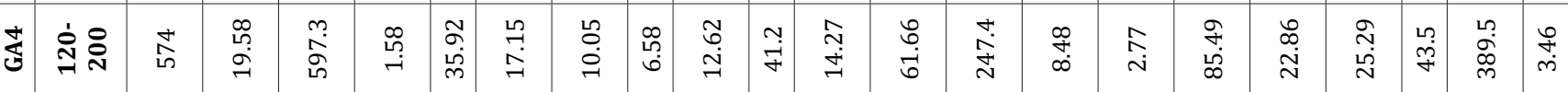

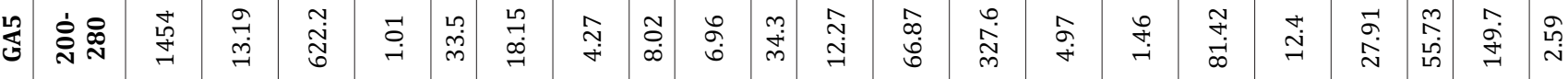

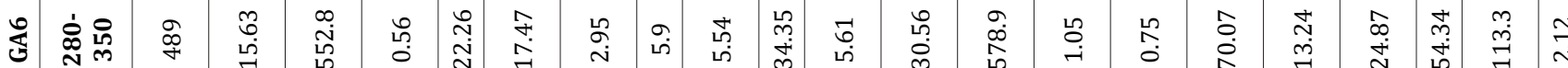

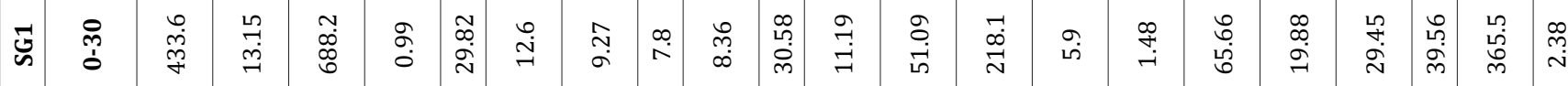

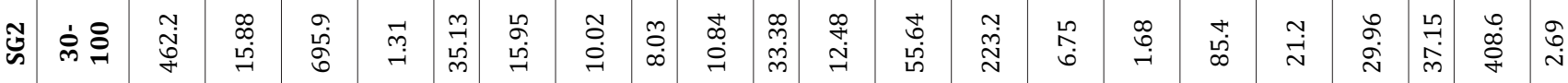

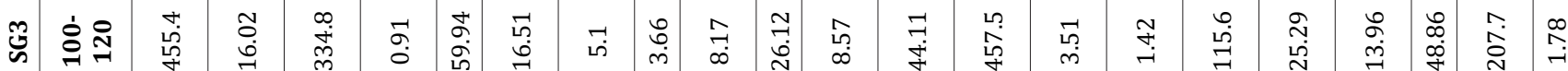

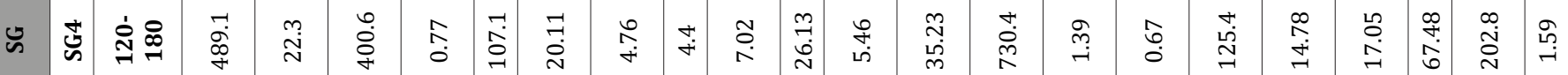

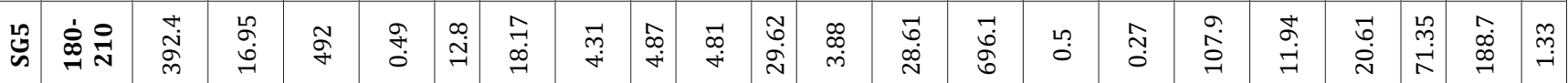

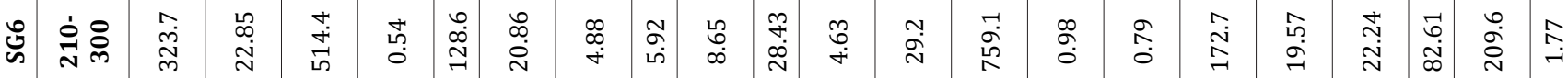

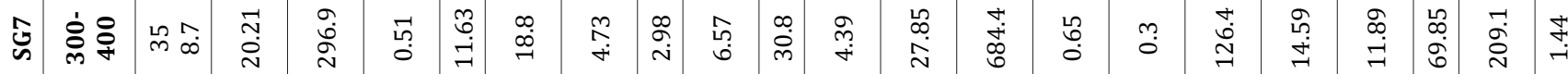

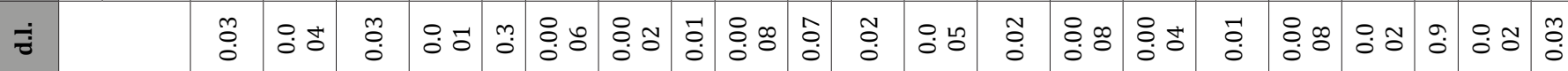

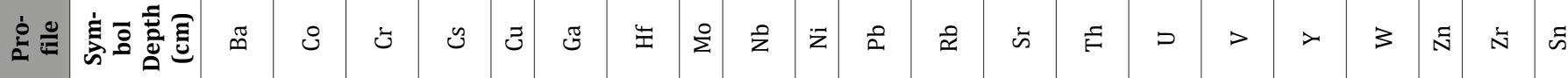




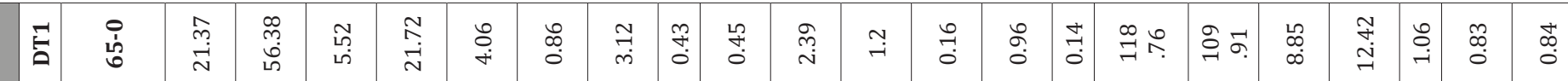

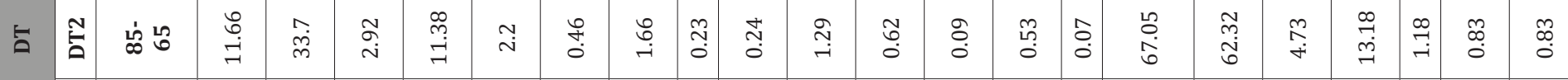

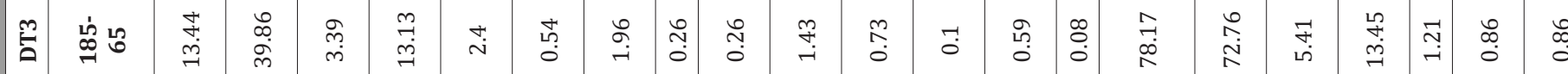

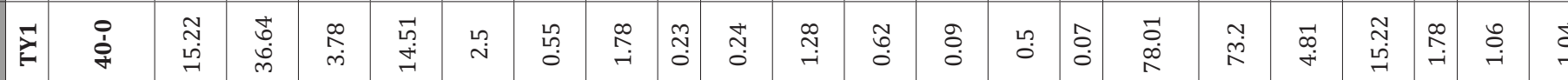

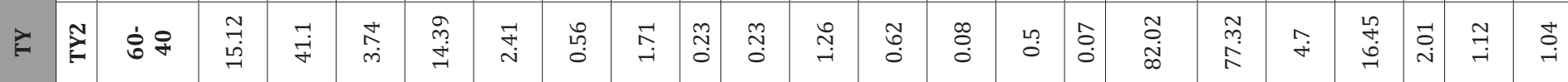

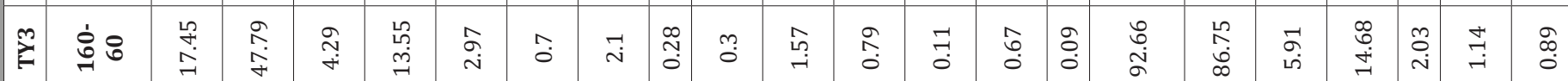

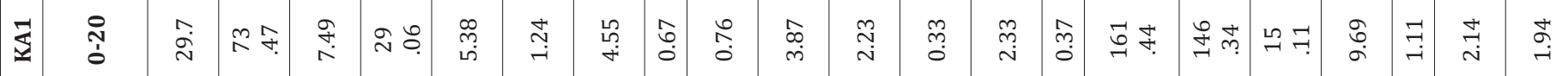

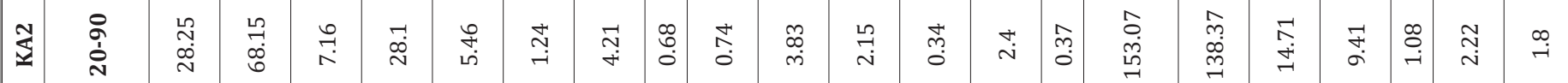

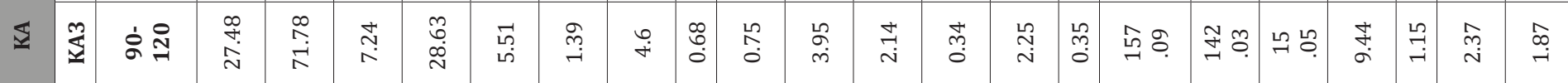

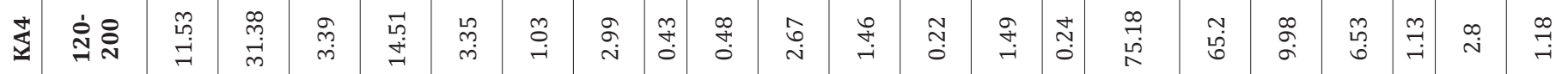

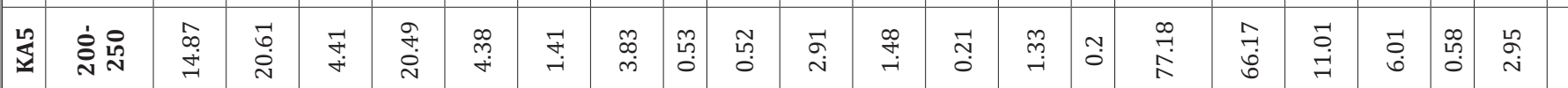

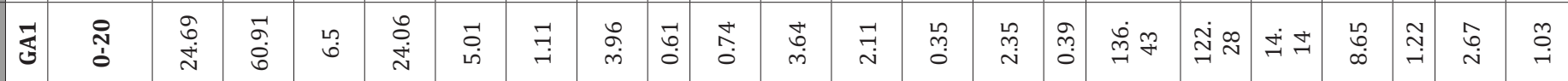
芯

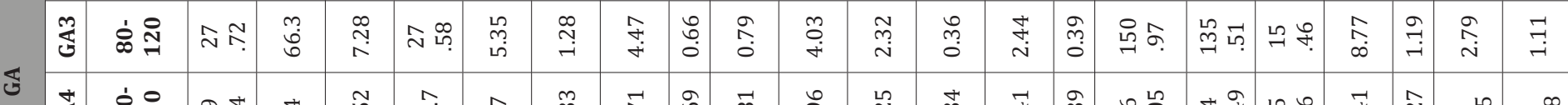

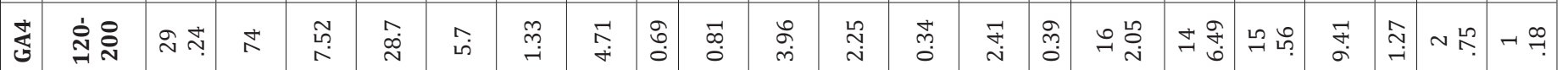

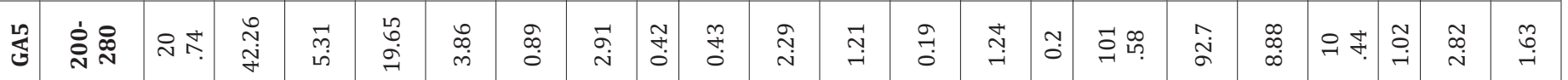

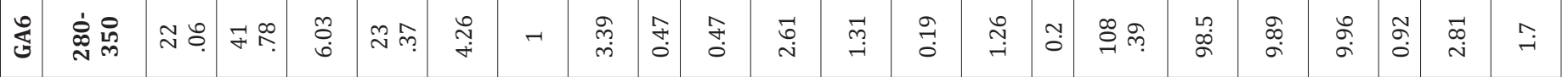

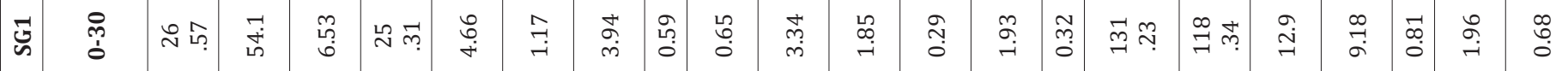
岕

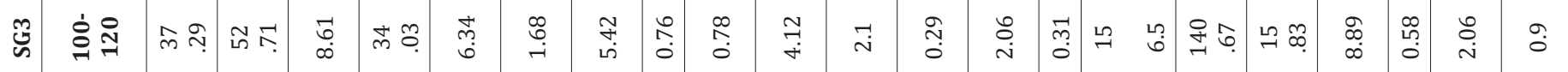
乡

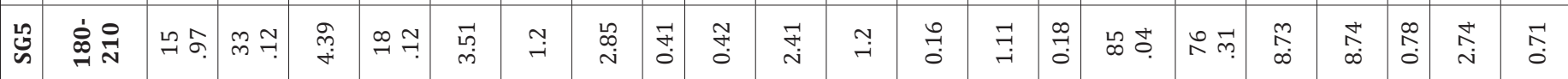
岕 岕

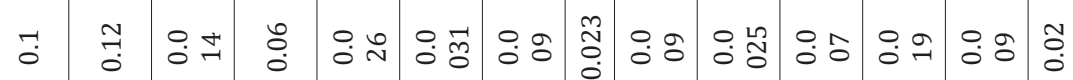

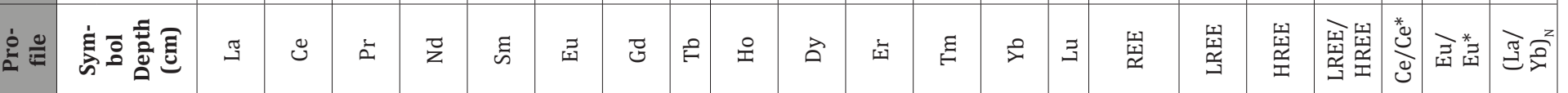


Rare earth elements concentrations in the profile samples are presented in Table 5. The REE has low to moderate concentrations in the Vertisols developed on S-type granite of Kaele (Table 5). There is a relative LREE enrichment compared to HREE which is more expressed in TY and DT profiles. Correlations between rare earth elements and major elements in Vertisols of Kaele are scarce
(Figure 5). REE present no significant correlations with $\mathrm{SiO}_{2}, \mathrm{Al}_{2} \mathrm{O}_{3}$, $\mathrm{K}_{2} \mathrm{O}, \mathrm{MgO}$ and $\mathrm{CaO}$ (Figures 5a-e). Meanwhile, $\mathrm{REE}$ and $\mathrm{Na}_{2} \mathrm{O}$ are negatively correlated (Figure 5f) and slight positive correlation is observed between $\mathrm{REE}$ and $\mathrm{Fe}_{2} \mathrm{O}_{3}$ (Figure 5g). There is a strong positive correlation between REE and loss on ignition which represents the degree of weathering (Figure 5h).
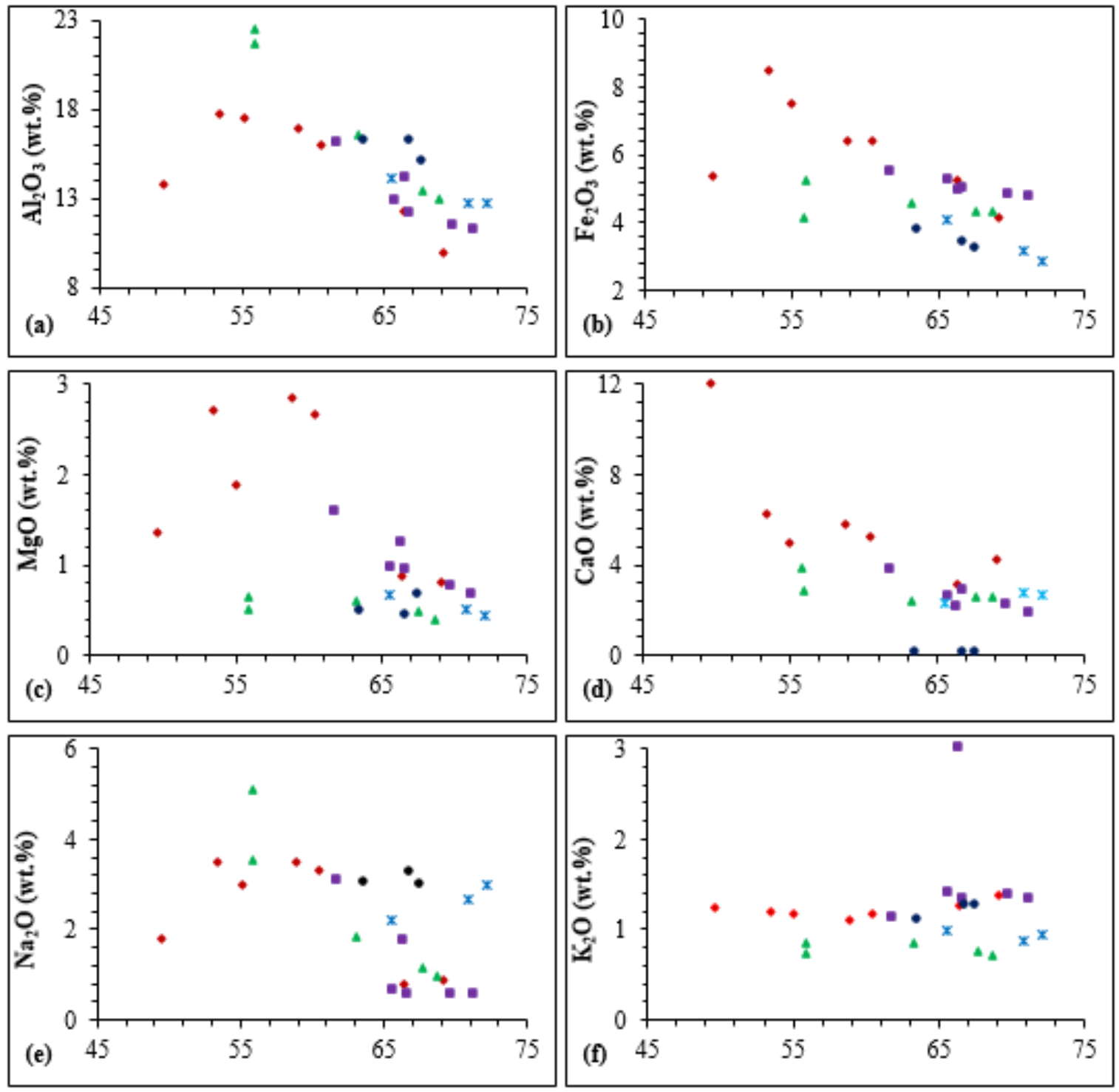

$\mathrm{SiO}_{2}$ (wt. \%)

$\mathrm{SiO}_{2}(\mathrm{wt} . \%)$

\section{- SG profile = GAprofile ^KA profile - TY profile *DTprofile}

Figure 3: Representative weathering profile description of Vertisols developed on granite of Kaele area (GA profile).

The normalized spectra relative to the parent rocks indicate lanthanide enrichments in SG, GA, TY and DT profiles (Figure 6). The lanthanide contents in the TY profile are ten times higher than values reported for the parent rock (Figure 6f) and the enrichment is very slight for GA and DT profiles (Figures $6 \mathrm{~b}$ and e). Apart from
$\mathrm{Eu}$, all the lanthanides show depletion in the KA profile compared to its parent rock (Figure $6 \mathrm{c}$ ). The parent rock-REE normalized spectra also reveal (Figure 5 and Table 6): (i) the presence of positive Eu anomalies in SG, GA and KA profiles (Figure 6a-c); (ii) the presence of negative $\mathrm{Eu}$ anomalies in DT profiles $\left(\mathrm{Eu} / \mathrm{Eu}^{*}=0.83-0.86\right.$; Figure 
6e); (iii) negative $\mathrm{Ce}$ anomalies in SG profile $\left(\mathrm{Ce} / \mathrm{Ce}^{*}=0.58-0.90\right.$; Figure $6 \mathrm{a})$ and at the bottom of KA profile $\left(\mathrm{Ce} / \mathrm{Ce}^{*}=0.58\right.$; Figure 6c); (iv) positive Ce anomalies in $\mathrm{GA}\left(\mathrm{Ce} / \mathrm{Ce}^{*}=1.19-1.27\right.$; Figure 6b), TY (Ce/Ce* =1.78-2.01; Figure 6d) and DT (Ce/Ce*=1.18-1.21; Figure 6e) profiles; (v) very low values of the $(\mathrm{La} / \mathrm{Yb})_{\mathrm{N}}$ ratios (fractionation degree), lower than 2 (Table 5).

\section{Mass balance evaluation}

The mass balance calculations show variable behavior of major, trace and rare earth elements in the different weathering profiles as presented in Figures 7, 8 and 9.

In SG profile, major elements are leached from the whole profile with $\mathrm{SiO}_{2}, \mathrm{Al}_{2} \mathrm{O}_{3}$ and $\mathrm{Na}_{2} \mathrm{O}$ as the most leached oxides (Figure 7a). $\mathrm{MgO}$ and LOI have variable behavior along the variable (Figure 7a). Amongst major elements, $\mathrm{SiO}_{2}, \mathrm{Al}_{2} \mathrm{O}_{3}, \mathrm{MgO}, \mathrm{CaO}$ and $\mathrm{Na}_{2} \mathrm{O}$ are leached while $\mathrm{MnO}$ and $\mathrm{LOI}$ accumulated in whole GA profile (Figure 7b). The accumulation of $\mathrm{MnO}$ and LOI increases from the top to the bottom of the profile. $\mathrm{K}_{2} \mathrm{O}$ and $\mathrm{P}_{2} \mathrm{O}_{5}$ are remobilized towards the bottom of the profile (Figure $7 \mathrm{~b}$ ). Apart from $\mathrm{CaO}$ and LOI, major elements are mobilized in the entire KA profile (Figure 7c). $\mathrm{CaO}$ is accumulated at the bottom of the profile while LOI is remobilized in the whole profile (Figure $7 \mathrm{c}$ ). The spectra are similar for TY profile, $\mathrm{MgO}, \mathrm{K}_{2} \mathrm{O}$, LOI are enriched while $\mathrm{Fe}_{2} \mathrm{O}, \mathrm{CaO}$ and $\mathrm{Na}_{2} \mathrm{O}$ are leached in the whole profile (Figure $7 \mathrm{~d}$ ). Conversely, $\mathrm{MnO}$ is highly accumulated in DT profile and the other major elements are remobilized (Figure 7e).
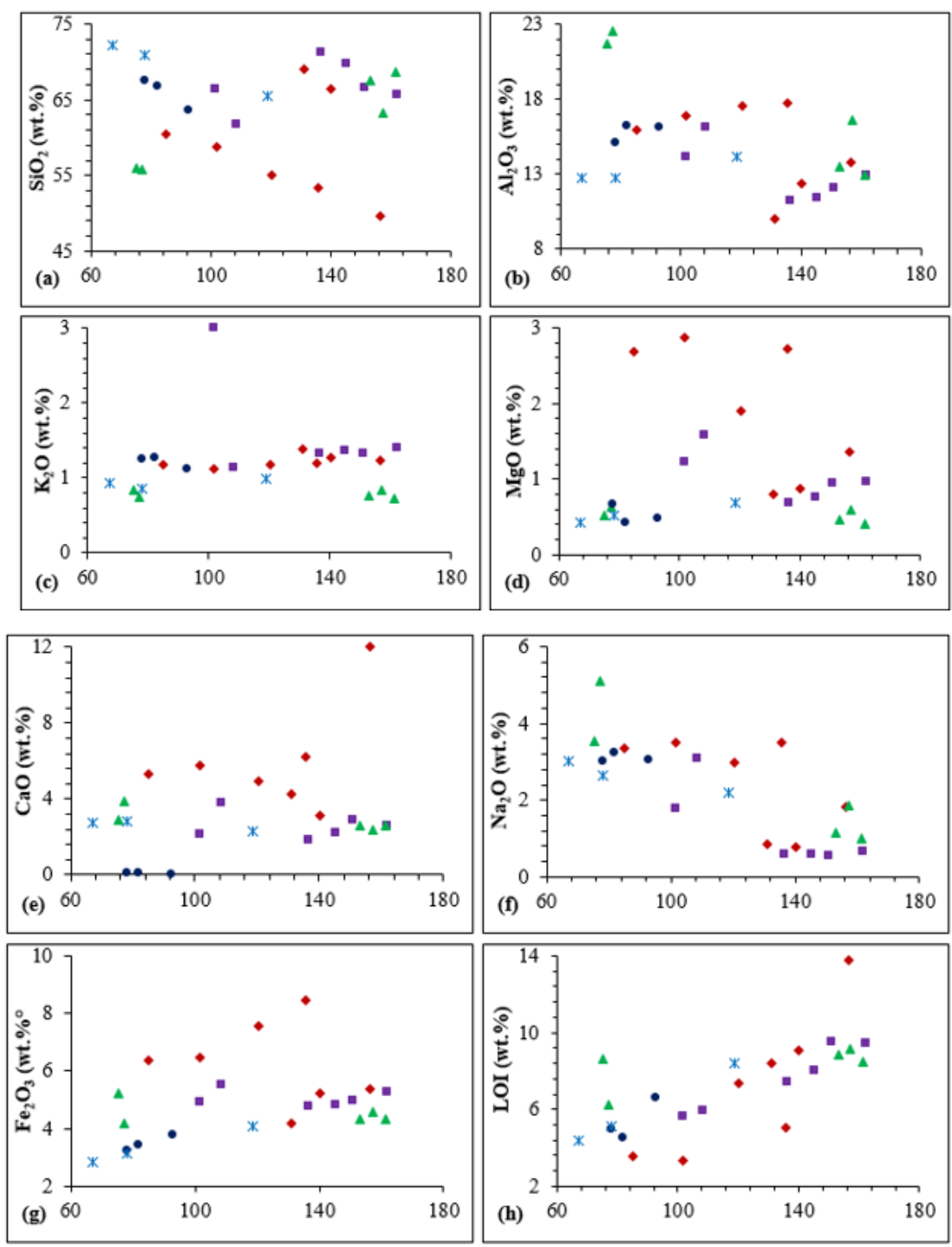

REE (ppm)

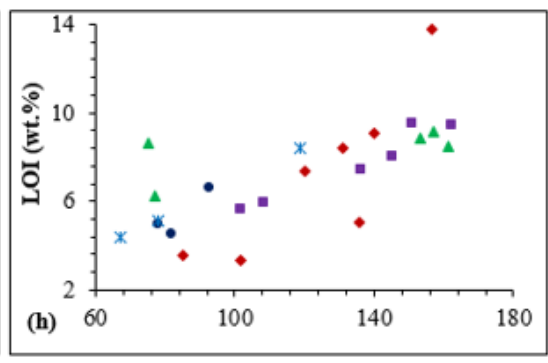

REE (ppm)

- SG profile = GA profile $\triangle$ KA profile $\quad$ TY profile $\times$ DTprofile

Figure 4: Bivariant plots of Vertisols showing REE contents against major elements contents: (a) $\mathrm{REE}$ vs. $\mathrm{SiO}_{2} ;(\mathrm{b}) \mathrm{REE}$ vs. $\mathrm{Al}_{2} \mathrm{O}_{3}$; (c) $\mathrm{REE}$ vs. $\mathrm{K}_{2} \mathrm{O}$; (d) REE vs. MgO; (e) REE vs. CaO; (f) REE vs. $\mathrm{Na}_{2} \mathrm{O}$; (g) REE vs. $\mathrm{Fe}_{2} \mathrm{O}_{3}$ and (h) REE vs. LOI. 

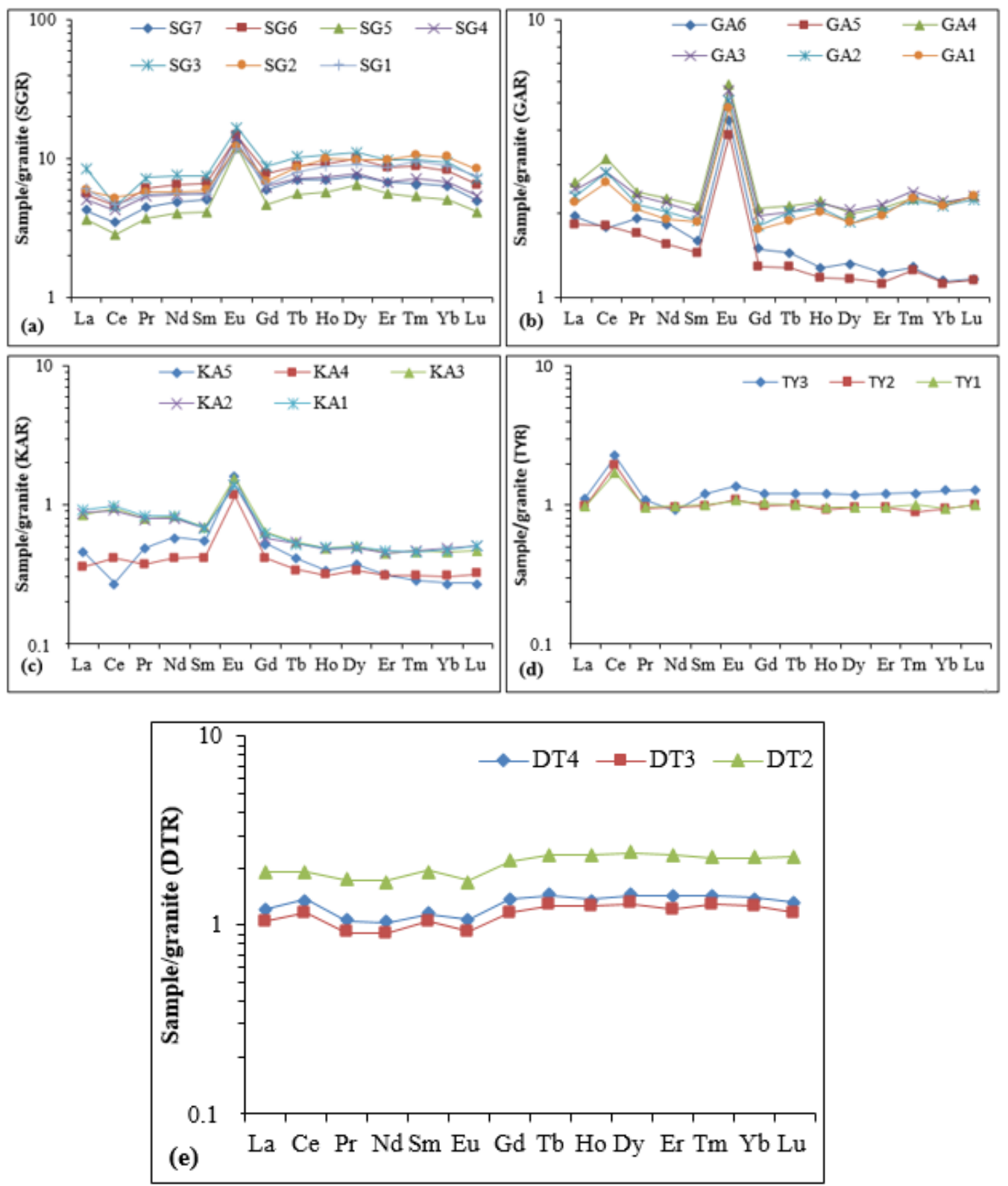

Figure 6: Chondrite-normalized (Pourmand et al., 2012) REE patterns of Vertisols of Kaele area.SG (a), GA (b), KA (c), TY (d), DT (e) and DR (f) profiles.

Amongst trace elements, $\mathrm{Nb}$ and $\mathrm{Y}$ are accumulated in the SG profile and in the GA profile, most of the trace elements are accumulated, especially towards the surface of the profiles (Figures $8 \mathrm{a}$ and b). Only Sr and V are accumulated in the entire KA profile and $\mathrm{Co}, \mathrm{Cs}$ and $\mathrm{Ni}$ are remobilized towards the top of the profile (Figure 8c). The different samples in TY and DT profiles show similar spectra (Fig. 8d and e). Several elements such as $\mathrm{Ba}, \mathrm{Co}$, $\mathrm{Cr}, \mathrm{Cs}, \mathrm{Ga}, \mathrm{Ni}, \mathrm{Rb}, \mathrm{V}, \mathrm{Y}$ and $\mathrm{Sn}$ are accumulated in the whole TY and DT profiles. In addition, $\mathrm{Cu}$ and in a lesser extent $\mathrm{U}$ are so much accumulated in the DT profile (Figure 8e).

The spectra showing relative chemical gains and losses of rareearth elements display similar trend in each profile (Figure 9). In general, the accumulation degree increases from the bottom to the top of the profiles. Specifically, Eu is so much accumulated in GA profile and to a lesser extent in SG profile (Figure 9a and b). LREE are leached in the whole SG profile while HREE are remobilized towards the top of the profile (Figure 9a). All the REE are accumulated in the GA profile with HREE the less accumulated REE at the bottom of the profile (Figure 9b). Conversely, all the REE are mobilized from KA profile with Eu the less leached REE (Figure 9c). The REE accumulation degree, contrary to SG profile, increase from the top to the bottom of the TY profile with Ce highly accumulated in the whole profile (Figure 10d). In the DT profile, only HREE are accumulated at the top of the profile (Figure 9e). 

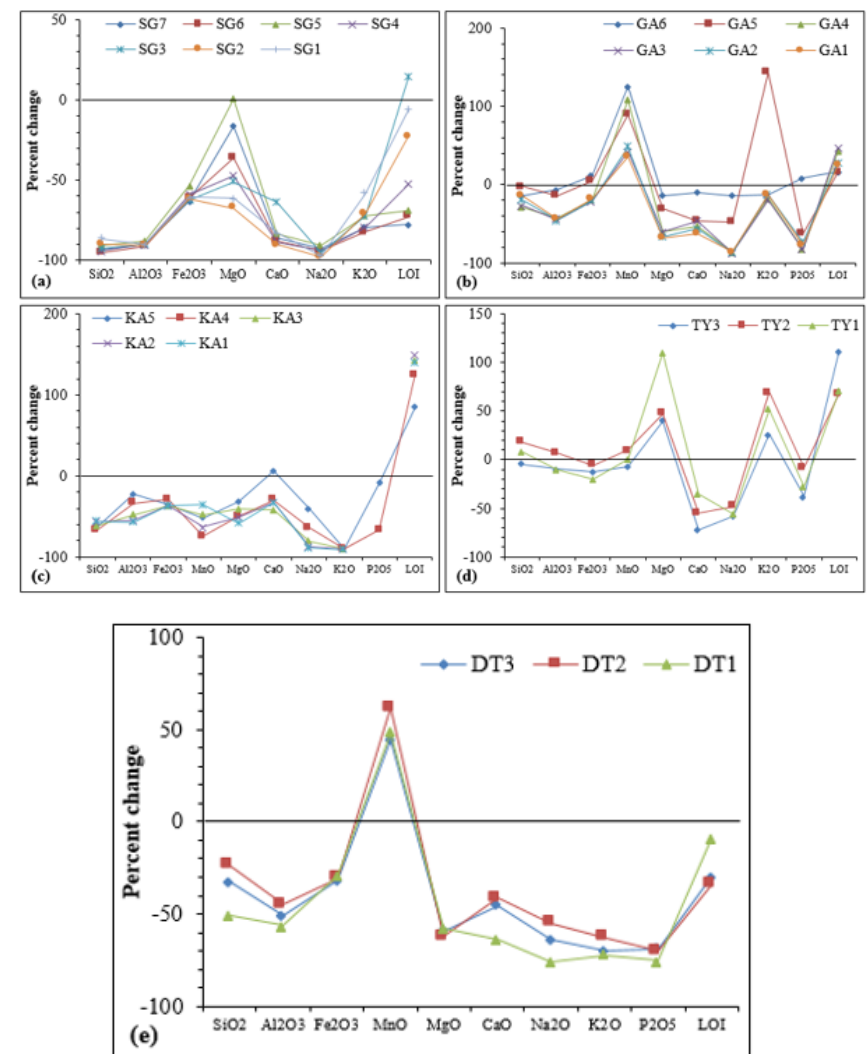

Figure 7: Spectra showing relative chemical gains and losses of major elements in Vertisols of Kaele area.SG (a), GA (b), KA (c), TY (d), DT (e) and DR (f) profiles.
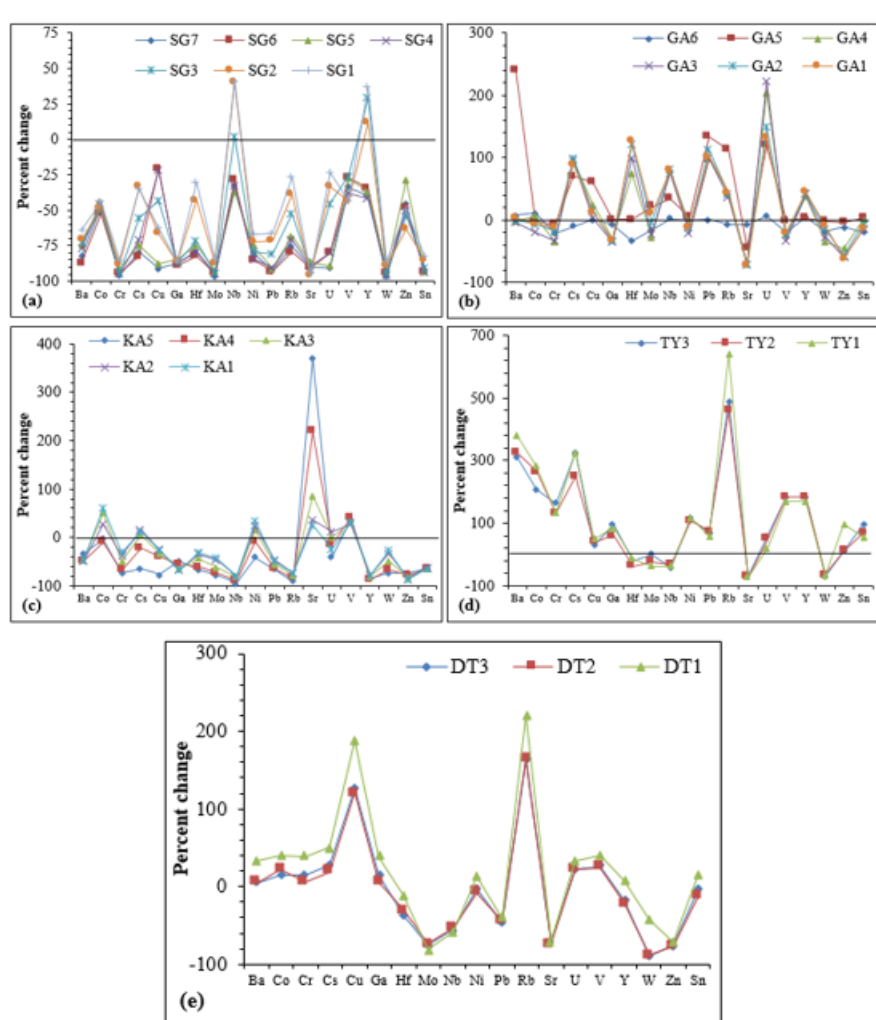

Figure 8: Spectra showing relative chemical gains and losses of trace elements in Vertisols of Kaele area.SG (a), GA (b), KA (c), TY (d), DT (e) and DR (f) profiles. 

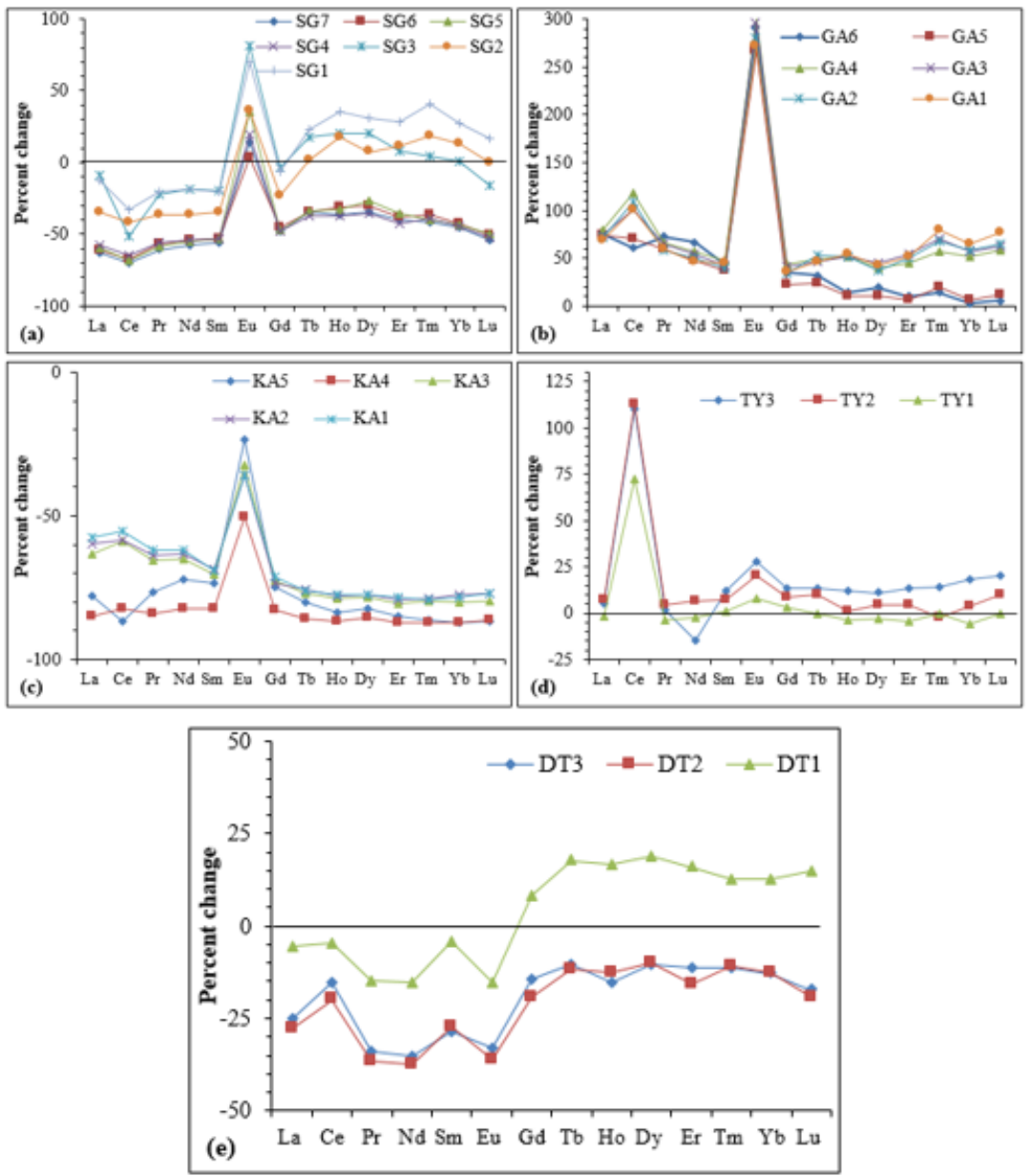

Figure 9: Spectra showing relative chemical gains and losses of rare earth elements in Vertisols of Kaele area.SG (a), GA (b), KA (c), TY (d), DT (e) and DR (f) profiles.

\section{Discussion}

\section{Geochemistry of granites}

Silicon and aluminum contents followed by those of sodium and potassium are significant in the granites of Kaele. The high $\mathrm{Al}_{2} \mathrm{O}_{3}$ and very low $\mathrm{TiO}_{2}$ concentrations in granites are characteristic of felsic igneous rocks $[39,40]$. They are S-type granites with peraluminous composition which may derive from biotite in congruent melting of a metasedimentary source close to the base of the crust [41]. High contents in $\mathrm{Ba}, \mathrm{Cr}$, $\mathrm{Sr}$ and $\mathrm{Zr}$ might result from the greisenization and albitization processes [42,43] and/or the high proportion of feldspars and biotite [39,44]. Trace element concentrations in S-type granites generally increase with maficity [41]. So, SGR, GAR and KAR show mafic tendency as confirmed by their high $\mathrm{Cr}$ contents. The low concentrations of several trace elements indicate that they might be essentially held by accessory phases [45]. And, accessory minerals are generally dissolved by melts of fluids [45].

The total REE contents in granites of Kaele are lower than those reported in other areas of Cameroon $[44,46]$. Despite the low REE content, the granite of Kaele shows relative enrichment in light
REE over heavy REE. Several authors [44,46,47] have explained that the high LREE concentrations in granite suggest that the liquid mantle might have been enriched in light REE. In general, accessory minerals such as monazite, apatite and zircon control the REE contents in granitoids [48]. Monazite is responsible for most of LREE abundance while zircon controls most of HREE [39]. The negative europium anomalies may result from high degree of plagioclase fractionation at the early stage of weathering, notably in reducing conditions [48]. The positive or absence of Eu anomalies could be linked to the stability of Eu rich minerals. Definitely and despite the variable values, the low REE contents in general may result from depletion of REE rich-minerals $[39,48]$ as confirmed by petrographycal observation.

\section{Geochemistry of Vertisols}

The mineralogical and geochemical features of weathering products mostly depend on the nature of parent rock and the intensity of the weathering processes [49]. The weathering processes lead to the formation of clay materials which are new minerals stable in the supergene environment. The high 
$\mathrm{SiO}_{2}$ contents might be related to the low degree of quartz dissolution. From the parent rocks to the weathered materials, the remobilization of $\mathrm{Fe}$ is observed contrary to $\mathrm{Si}, \mathrm{Al}$ and $\mathrm{Na}$. That could be originated from precipitation of Fe-oxides and dissolution of quartz as confirmed by the negative correlation between $\mathrm{SiO}_{2}$ and $\mathrm{Fe}_{2} \mathrm{O}_{3}$ [29]. The presence of calcareous nodules is responsible for high $\mathrm{CaO}$ contents and dolomite lead to the increase of $\mathrm{MgO}$ contents. The negative correlation between $\mathrm{SiO}_{2}$ and $\mathrm{Al}_{2} \mathrm{O}_{3}$ may be linked to the formation of kaolinite minerals. The low contents of most of major elements and the lack of correlation with $\mathrm{SiO}_{2}$ reflect the high content of $\mathrm{SiO}_{2}$, which causes a dilution effect.

Vertisols of Kaele have high contents in $\mathrm{Sr}, \mathrm{Ba}, \mathrm{Cr}, \mathrm{Zr}$ and $\mathrm{Zn}$ as their parent rocks. In addition, and contrary to the parent rocks, they have significant contents in $\mathrm{Co}, \mathrm{Cu}, \mathrm{Rb}$ and $\mathrm{V}$. In general, high concentrations of $\mathrm{Cr}, \mathrm{V}$ and Co generally originate from weathering of ultramafic rocks [32] and $\mathrm{Sr}, \mathrm{Ba}, \mathrm{Zr}, \mathrm{Cu}, \mathrm{Rb}$ and $\mathrm{Zn}$ are controlled by felsic parent rocks [43]. These high contents in $\mathrm{Cr}, \mathrm{V}$ and $\mathrm{Co}$ can only be justified by the fact that they are remobilized during weathering process while other elements are leached.

REE contents in soil particularly depend on the type of the parent rock as well as the weathering process [50]. However, it is not easy to define which factor between them is the dominant [11]. According to Šmuc et al. [51], the soils derived from granite tend to have higher REE concentrations. The REE contents increase with depth as the clay quantity. In fact, during weathering of granite, the accumulation of clay increases from the upper to the lower horizons $[51,52]$. Generally, soils derived from granites are enriched in LREE, particularly in Ce, Nd and La [7,53]. LREE is less mobile than HREE during weathering and HREE are depleted in high weathered material [54]. LREE-enrichment is inherited from the parent material or due to the formation of secondary LREE-bearers as rhabdophane ( LREEPO $_{4} \cdot \mathrm{nH}_{2} \mathrm{O}$ ) [55]. The concentrations of REE in the Vertisols from Kaele area are higher than those of Ferralsols [56] and Lixisols [57] in Cameroon. Similar results have been observed in Brazilian soils [7], where REE in Vertisols have a higher content than in other soils. Moreover, the REE concentrations in Vertisols of Kaele area are lower than the values reported for soils in China [58] and Malaysia [59]. The low REE contents result from depletion of REE rich minerals inherited from the parent rocks. The strong positive correlation between REE and loss on ignition highlight the important role of weathering process in REE remobilization. The high positive Eu anomalies in SG, GA, KA and TY profiles could be explained by the stability of Eu rich minerals in these profiles. On the other hand, Eu bearing minerals have been destabilized in DT and DR profile. There are negative Ce anomalies in SG profile, at the bottom of KA profile and positive Ce anomalies in GA, TY and DT profiles. The variation in Ce anomalies in the Vertisols of Kaele can be explained by the variability of the oxidation conditions [29]. The positive Ce anomalies are linked to the oxidation of $\mathrm{Ce}^{3+} t_{0 C e^{4+}}$ which is stable in weathering profile [60]. The low fractionation degree of REE may be due to the environment which is not well drained and the homogenization of the profiles by seasonal deep surficial desiccation cracks.

\section{Mass balance assessment}

The depletion $\mathrm{in}_{2} \mathrm{SiO}_{2}, \mathrm{Al}_{2} \mathrm{O}_{3}, \mathrm{Na}_{2} \mathrm{O}, \mathrm{K}_{2} \mathrm{O}$ and $\mathrm{P}_{2} \mathrm{O}_{5}$ is characteristic of the lateritization $[29,30]$. Weathering processes are responsible for the increase of LOI values. The accumulation of many trace elements might result from the stability of secondary bearing minerals and the persistence of relic minerals. The similarity of several spectra of mass balance evaluation highlights the undifferentiated nature of the profiles. The REE-accumulation especially towards the surface of the profile might be due to the element redistribution during the weathering or to the element substitution in secondary minerals [61]. The increasing accumulation degrees of REE from the bottom to the top of profiles are better expressed in the thick and well differentiate profiles like SG, GA and KA profiles. In TY profile, the remobilization degree of REE decreases from the bottom to the top of the profile. This is due to the element redistribution and the profiles are so much homogenized by desiccation cracks and other phenomena in soils. The similar spectra of REE mass balance evaluation confirm their coherent geochemical behavior, low solubility and low impact of weathering processes $[62,63]$.

\section{Conclusion}

This study assessed REE concentrations in Vertisols developed on granite setting under seasonally contrasted climate of North Cameroon. The main conclusions are as follows:

- Kaele granites consist of feldspars, quartz, amphiboles, biotites and opaque mineral. They are S-type granites with peraluminous composition, low REE contents and variable Eu anomalies.

- Vertisols were characterized by a dark colour, a heavy clayey texture, massive structure, low porosity, high compacity and deep open surficial desiccation cracks, but also by the development of frictional surfaces (slickensides) in the middle part of the profile and made up of beidellite, montmorillonite, and kaolinite with small amount of quartz.

- The geochemical composition of Vertisols is in general similar to that of the parent rocks apart from some element remobilizations. REE contents are strongly correlated with the degree of weathering.

- Despite the REE remobilization during weathering, Vertisols of Kaele have low REE contents which are inherited from the parent rocks. The very low values of the $(\mathrm{La} / \mathrm{Yb})_{\mathrm{N}}$ ratios are due to the undifferentiated weathering profiles.

\section{Acknowledgment}

We extend our gratitude to Professor Njilah Isaac Konfor and Doctor Tessontsap Teutsong for the helpful advice during the drafting of the manuscript and improving the English style. 


\section{Conflict of Interest}

No conflict of interest.

\section{References}

1. JP Temga, TP Azinwi, DS Basga, P Zo'o Zame, H Gouban, et al. (2019) Characteristics, classification and genesis of Vertisols under seasonally contrasted climate in the Lake Chad Basin, Central Africa. J Afr Earth Sci 150: 176-1933.

2. NK Moustakas (2012) A study of Vertisols genesis in North Eastern Greece. Catena 92: 208-215.

3. S Grunwald (2003) Vertisols: environmental conditions, processes, pedogenetic models, properties and classification. Journal of soil and water sciences, Univ Florida, IUSS soil bulletin, 104p.

4. H Eswaran, T Cook (1988) Classification and management related properties of Vertisols. In: proceedings of the of a Conference held at ILCA on the management of Vertisols in Sub Saharan Africa, SC Jutsi, I Haque, J McIntire, J shares (Eds)., Adis Ababa, Ethiopia, pp. 64-84.

5. JP Temga, JP Nguetnkam, A Balo Madi, SD Basga, DL Bitom (2015) Morphological, physico chemical, mineralogical and geochemical properties of Vertisols used in bricks production in the Logone Valley (Cameroon, Central Africa). Int Res J Geol Min 5(1): 20-30.

6. P Oliva, J Viers, B Dupré (1999) The effect of organic matter on chemical weathering: study of a small tropical watershed: Nsimi-Zoetele site, Cameroon. Geochim Cosmochim Acta 63: 4013-4035.

7. HDS De Paye, JWV de Mello, GR Lima de Magalh, Mascarenhas M (2015) Gasparon Distribution and fractionation of the rare earth elements in Brazilian soils. J Geochem Explor 161: 27-41.

8. H Chu, G Chi, S Bosman, C Card (2015) Diagenetic and geochemical studies of sandstones from drill core DV10-001 in the Athabasca basin, Canada, and implications for uranium mineralization. J Geochem Explor 148: 206-230.

9. C Laveuf, S Cornu, LRG Guilerme, F Juillot (2012) The impact of redox conditions on the rare earth element signature of redoximorphic features in a soil sequence developed from limestone. Geoderma 170: 2538.

10. C Huang, C Wang (2004) Geochemical characteristics and behaviors of rare earth elements in process of Vertisols development. Journal of rare earths 22(4): 552-557.

11. W Fu, X Li, Y Feng, M Feng, Z Peng, et al. (2019) Chemical weathering of S-type granite and formation of Rare Earth Element (REE)-rich regolith in South China: Critical control of lithology. Chem Geol 520: 33-51.

12. L Miao, R Xu, J Xu (2007) Geochemical characteristics of rare earth elements (REEs) in the soil-plant system in West Guangdong Province. Acta Pedologica Sinica 44(1): 54-62.

13. J Mihajlovic, J Rinklebe (2018) Rare earth elements in German soils - A review. Chemosphere 205: 51-523.

14. K Sanematsu, Y Kon, A Imai, K Watanabe, Y Watanabe (2013) Geochemical and mineralogical characteristics of ion-adsorption type REE mineralization in Phuket, Thailand. Miner Deposita 48: 437-451.

15. M Hoshino, K Sanematsu, Y Watanabe (2016) REE Mineralogy and Resources in Handbook on the Physics and Chemistry of Rare Earths 49: 129-163.

16. V Balaram (2019) Rare earth elements: A review of applications, occurrence, exploration, analysis, recycling, and environmental impact. Geoscience Frontiers.

17. JB Suchel (1987) Les climats du Cameroun (Thèse d'Etat). Université de Bordeaux III, 1186p.

18. Yann L'hôte (2000) Climatologie. In: Atlas de la province de l'Extrême Nord-Cameroun. Eds. C. Seignobos. Et O. Iyebi-Mandjek, IRD. MINREST, Paris, pp. 27-33.
19. JP Nguetnkam, R Kamga, F Villiéras, GE Ekodeck, J Yvon (2008) Altération différentielle du granite en zone tropicale. Exemple de deux séquences étudiées au Cameroun (Afrique centrale). CR Geoscience 340: 451-461.

20. WGW IUSS (2015) World Reference Base for Soil Resources 2014, update 2015, International soil classification system for naming soils and creating legends for soil maps. World Soil Resources Reports No. 106. FA0, Rome, 203p.

21. FAO (2006) Guidelines for soil description, a framework for international classification, correlation and communication. FAO-ISRIC-IUSS, 4th edition, Rome, 128p.

22. EO McLean (1982) Soil pH and lime requirement, in Methods of Soil Analysis, Part 2, Chemical and Microbiological Properties, D.R. Buxton, Ed. Madison: American Society of Agronomy Inc. and Soil Science Society of America Inc, pp. 199 - 224.

23. DW Nelson, LE Sommers (1982) Total Carbon, Organic Carbon and Organic Matter, In Methods of Soil Analysis, Part 2, Chemical Analysis, DR Buxton, Ed. Madison: American Society of Agronomy Inc. and Soil Science Society of America Inc, pp. 539-579.

24. JM Bremner, CS Mulvaney (1982) Total Nitrogen, in Methods of Soil Analysis, Part 2, Chemical Analysis, D.R. Buxton, Ed. Madison: American Society of Agronomy Inc. and Soil Science Society of America Inc, pp. 595-624.

25. GW Thomas (1982) Exchangeable cations, in Methods of Soil Analysis, Part 2, Chemical and Microbiological Properties, A.L. Page, R.H. Buxton, D.R. Miller Keeney, Eds., Madison: American Society of Agronomy Inc. and Soil Science Society of America Inc, pp. 159-165.

26. OM Burnham, J Schweyer (2004) Trace element analysis of geological samples by inductively coupled plasma-mass spectrometry at the Geoscience Laboratories: revised capacities due to improvements to instrumentation. Ont Geol Surv Open File Rep 6145(54): 1-20.

27. YJAB Da Silva, CWA Do Nascimento, CM Biondi (2017) Influence of metaluminous granite mineralogy on the rare earth element geochemistry of rocks and soils along a climosequence in Brazil. Geoderma 306: 28-39.

28. SA Ebah Abeng, PD Ndjigui, AB Aye, T Tessontsap, P Bilong (2012) Geochemistry of pyroxenites, amphibolites and their weathered products in the Nyong unit, SW Cameroon (NW border of Congo craton): implications for Au-PGE exploration. J Geochem Explor 114: 1-19.

29. PD Ndjigui, P Bilong, D Bitom, A Dia (2008) Mobilization and redistribution of major and trace elements in two weathering profiles developed on serpentinites in the Lomié ultramafic complex, South-East Cameroon. J Afr Earth Sci 50: 305-328.

30. A Beauvais (2009) Ferricrete biochemical degradation on the rainforest-savannas boundary of Central African Republic. Geoderma 150: 379388.

31. J Wimpenny, A Gannoun, KW Burton, M Widdowson, RH James, et al. (2007) Rhenium and osmium isotope and elemental behaviour accompanying laterite formation in the Deccan region of India. Earth Planet Sci Lett 261: 239-258.

32. E Sababa, PD Ndjigui, SA Ebah Abeng, P Bilong (2015) Geochemistry of peridotite xenoliths from the Kumba and Nyos areas (southern part of the Cameroon Volcanic Line): implications for Au-PGE exploration. J Geochem Explor 152: 75-90.

33. S Cornu, Y Lucas, E Lebon, JP Ambrosi, F Luizão, et al. (1999) Neal, Evidence of titanium mobility in soil profiles, Manaus, Central Amazonia. Geoderma 91: 281-295.

34. JA Grant (2005) Isocon analysis: a brief review of the method and applications. Phys Chem Earth 30: 997-1004.

35. HW Nesbitt, RE Wilson (1992) Recent chemical weathering of basalts. American Journal of Science 292: 740-777.

36. M Moroni, VAV Girardi, A Ferrario (2001) The Serra Pelada Au-PGE deposit, Serra dos Carajas (Para state, Brazil): geological and geochemical indications for a composite mineralising process. Mineralium Deposita 36: 768-785. 
37. LM Chen, GL Zhang, ZD Jin (2014) Rare earth elements of a 1000-year paddy soil chronosequence: Implications for sediment provenances, parent material uniformity and pedological changes. Geoderma 230/231: 274-279.

38. A Pourmand, N Dauphas, TJ Ireland (2012) A novel extraction chromatography and MC-ICP-MS technique for rapid analysis of REE, Sc and Y: Revising CI-chondrite and Post-Archean Australian Shale (PAAS) abundances. Chem Geol 291: 38-54.

39. PR Bassanak Ongboye, E Sababa, F Ndong Bidzang, PD Ndjigui (2019) Geochemical characterization of surface sediments from Tongo Gandima (Eastern Cameroon): implications for gold exploration. Arab J of Geosci 859(21): 9102

40. KI Hayashi, H Fujisawa, HD Holland, H Ohmoto (1997) Geochemistry of $\sim 1.9$ Ga sedimentary rocks from northeastern Labrador, Canada. Geochim Cosmochim Acta 61: 4115-4137.

41. A Villaros, G Stevens, JF Moyen, IS Buick (2009) The trace element compositions of S-type granites: evidence for the disequilibrium melting and accessory phase entrainment in the source. Contrib Miner Petrol 158: 543-561.

42. A Sharma, V Rajamani (2000) Major element, REE, and other trace element behaviorin amphibolite weathering under semiarid conditions in Southern India. J Geol 108: 487-496.

43. SP Vriend, MG Oosteron, RW Bussink, JBH Jansen (1985) Trace element behavior in the W-Sn granite of Regoufe, Portugal J Geochem Explor 23: 13-25.

44. P Bilong, PD Ndjigui, R Temdjim, E Sababa (2011) Geochemistry of peridotite and granite xenoliths during the early stage of weathering in the Nyos volcanic region (NW Cameroon): Implications for PGE exploration. Chem Er de Geochem 71: 77-86.

45. S Fourcade, CS Allègre (1981) Trace elements behavior in granite genesis: a case study the calc-alkaline plutonic association from the Querigut complex (Pyrénées, France). Contrib Miner Petrol 76: 177-195.

46. AP Kouske, CE Suh, RT Ghogomu, V Ngako (2012) Na-Metasomatism and Uranium Mineralization during a Two-Stage Albitization at Kitongo, Northern Cameroon: Structural and Geochemical Evidence. Int J Geosciences 3: 258-279.

47. G Tyler, T Olsson (2002) Conditions related to solubility of rare and minor elements in forest soils. J Plant Nutr Soil Sci 165: 594-601.

48. GM Saleh (2007) Geology and rare-earth element geochemistry of highly evolved, molybdenite-bearing granitic plutons, Southeastern Desert, Egypt. Chin J Geochem 26(4): 333-344.

49. AR Cabral, G Beaudoin, M Choquette, B Lehmann, JC Polonia (2007) Supergene leaching and formation of platinum in alluvium: evidence from Serro, Minas Gerais, Brazil. Mineral Petrol 90: 141-150.

50. C Laveuf, S Cornu (2009) A review on the potentiality of Rare Earth Elements to trace pedogenetic processes. Geoderma 154: 1-12.
51. NR Šmuc, T Dolenec, T Serafimovski, M Dolenec, P Vrhovnik (2012) Geochemical characteristics of rare earth elements (REEs) in the paddy soil and rice (Oryza sativa L.) system of Kočani Field, Republic of Macedonia. Geoderma 183/184: 1-11.

52. D Feng, D Chen, J Peckmann, G Bohrmann (2010) Authigenic carbonates from methane seeps of the northern Congo fan: microbial formation mechanism. Mar Petrol Geol 27: 748-756.

53. H Mao, C Liu, Z Zhao, J Yang (2017) Distribution of rare earth elements of granitic regolith under the influence of climate. Acta Geochim 36(3): 440-445.

54. BW Chappell, AJR White (1974) Two contrasting granite types. Pac Geol 8: $173-174$

55. JJ Braun, JR Ndam Ngoupayou, J Viers, B Dupré, JP Bedimo Bedimo, et al. (2005) Present weathering rates in a humid tropical watershed: Nsimi, South Cameroon. Geochim Cosmochim Acta 69: 357-7387.

56. BV Kamgang Kabeyene, VL Onana, PE Ndome Effoudou, JC Parisot, GE Ekodeck (2009) Behavior of REE and mass balance calculations in a lateritic profile over chlorite schists in South Cameroon. Chem Er de Geochem 69: 61-73.

57. LA Banakeng, P Zo'o Zame, R Tchameni, L Mamdem, D Bitom (2016) Mineralogy and geochemistry of laterites developed on chlorite schists in Tchollire region, North Cameroon. J Afr Earth Sci 119: 264-278.

58. FS Wei, CJ Zheng, JS Chen, YY Wu (1991) Study on the background contents on 61 elements of soils in China. Chin J Environ Sci 12: 12-20.

59. H Mohamad, AG Rafek (1993) The distribution of rare earth in tropical granitic soils: a case study from Malaysia. J Southeast Asian Earth Sci 8(1-4): 617-625.

60. A Manceau, ML Schlegel, M Musso, VA Sole, C Gauthier, et al. (2000) Crystal chemistry of trace elements in natural and synthetic goethite. Geochim. Cosmochim Acta 64: 3643-3661.

61. JK Tripathi, V Rajamani (2007) Geochemistry and origin of ferruginous nodules in weathered granodioritic gneisses, Mysore Plateau, Southern India. Geochim Cosmochim Acta 71(7): 1674-1688.

62. JS Armstrong-Altrin, YI Lee, JJ Kasper-Zubillaga, A Carranza-Edwards, D Garcia, et al. (2012) Geochemistry of beach sands along the western Gulf of Mexico, Mexico: implication for provenance. Chem Er de Geochem 72 : 345-362.

63. X Cao, P Wu, Z Cao (2016) Element geochemical characteristics of a soil profile developed on dolostone in central Guizhou, southern China: implications for parent materials. Geochim Cosmochim Acta 35(4): 445462. 